\title{
The Great Rebalancing Act: \\ Can Investment Be a Lever in Asia?
}

Malhar Nabar and Murtaza Syed 


\title{
IMF Working Paper
}

Asia and Pacific Department

\section{The Great Rebalancing Act: \\ Can Investment Be a Lever in Asia?}

\section{Prepared by Malhar Nabar and Murtaza Syed ${ }^{1}$}

Authorized for distribution by Roberto Cardarelli

February 2011

\section{This Working Paper should not be reported as representing the views of the IMF.}

The views expressed in this Working Paper are those of the author(s) and do not necessarily represent those of the IMF or IMF policy. Working Papers describe research in progress by the author(s) and are published to elicit comments and to further debate.

\begin{abstract}
Ensuring stable growth in the postcrisis world economy will require a rebalancing of economic activity in several countries. In Asia's export-dependent economies, this entails relying more on private domestic demand as a driver of growth. While some countries need to raise consumption, several need to raise investment or reorient it from tradable to nontradable sectors. These changes in investment could be facilitated by financial reforms that enhance domestically oriented firms' access to credit, stronger incentives for corporate restructuring, policies to bolster the business climate and reduce uncertainty, and by improvements in infrastructure that raise the returns to private investment.
\end{abstract}

JEL Classification Numbers: E22, F21, O53

Keywords: Rebalancing, investment, infrastructure, financing constraints

Author’s E-Mail Address: mnabar@imf.org; msyed@imf.org

\footnotetext{
${ }^{1}$ We thank, without implicating, Vivek Arora, Roberto Cardarelli, Josh Felman, Kenneth Kang, Olaf Unteroberdoerster, and seminar participants at RIETI, Tokyo; Bank Negara, Kuala Lumpur; the ASEM Conference, Mumbai; and Bank of Korea and Korea Development Institute, Seoul, for helpful comments, and Souvik Gupta for invaluable assistance.
} 


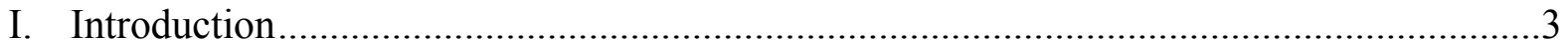

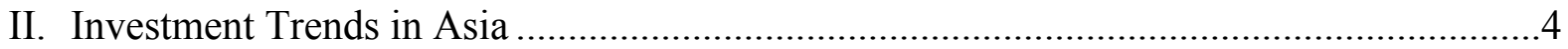

A. Recent Developments ..................................................................................

B. Investment Levels and Composition in Asia ..........................................................6

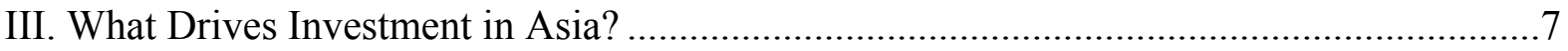

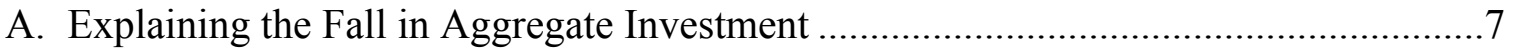

B. Why Has the Composition of Investment Changed? .............................................11

IV. Policy Implications: How Can Asia Facilitate Rebalancing Through Investment? .........17

A. Policies Suggested by Empirical Results ..............................................................18

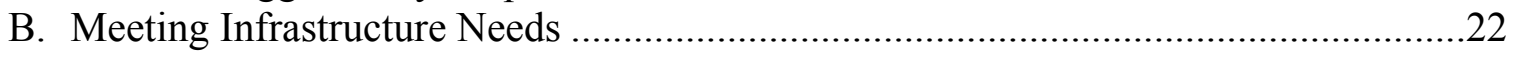

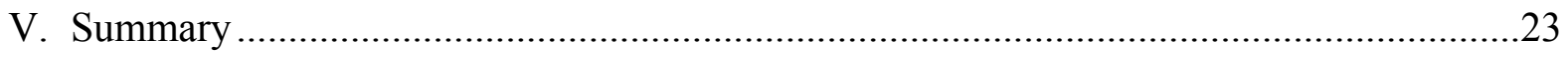

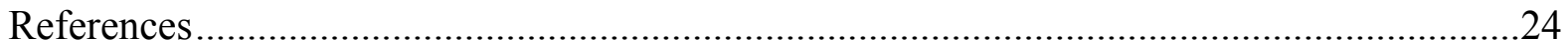

Figures

1. Selected Asia: Gross Fixed Capital Formation (GFCF) and Gross Saving,

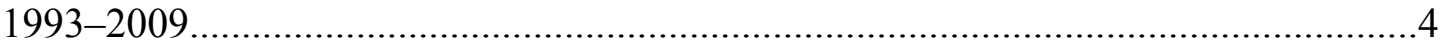

2. Export-Oriented Asia: Contribution to Change in Average Share of GFCF in GDP .........4

3. Selected Asia: Change in Investment by Type …..................................................

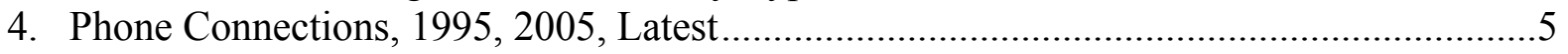

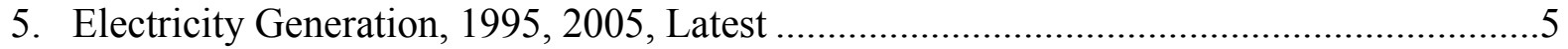

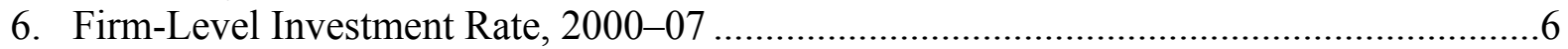

7. Composition of Investment by Sector, 1990, 2000, and 2007 ...................................... 7

8. NIEs: Firm-Level Investment Rate, by Size and by Sector, 2000 and 2008 ....................7

9. Export-Oriented Asia: GFCF - Change in Share versus Change in Relative Price ............8

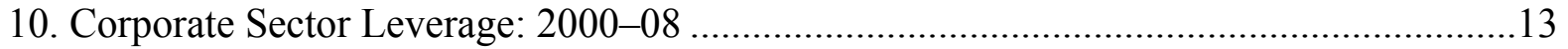

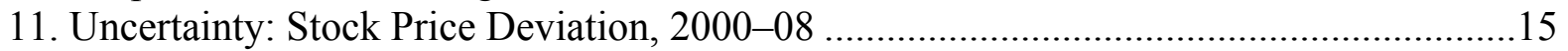

12. NIEs, Japan: Relative Change in Fundamentals .........................................................15

13. Effective Corporate Tax Rates in OECD....................................................................19

14. Size of the Corporate Bond Market, Selected Asian Economies, 2009...........................19

15. Venture Capital Investment: Selected Advanced Economies, 2006 ...............................20

Tables

1. Selected Financial Indicators for Firms, 1990-97 and 2000-07 .................................6

2. Determinants of Private Investment Spending ............................................................ 9

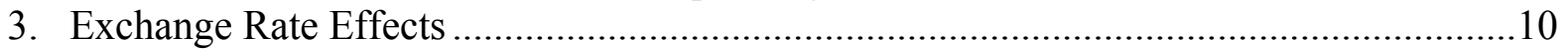

4. Effect of Infrastructure on Private Investment Spending ….......................................11

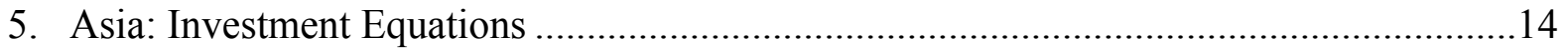

6. NIEs and Japan: Changes in Fundamentals, 1990-97 versus 2000-07 by Firm

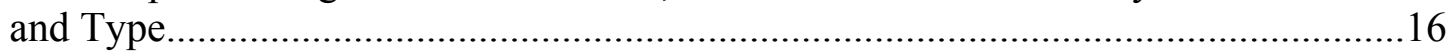

7. International Comparators: Investment Equations.................................................... 17

8. How Would an Improvement in Fundamentals Affect Investment in Asia?....................18 


\section{INTRODUCTION}

A common aspect of rebalancing growth in several Asian economies is reorienting production and spending away from external toward domestic drivers. One channel through which these objectives can be met is by promoting investment. ${ }^{1}$ This paper examines the case for rebalancing in Asia through the route of investment.

In contrast with existing work (Guimaraes and Unteroberdoerster, 2006; and Hori, 2008), this paper focuses on investment at both the aggregate level and the level of individual sectors across major Asian economies. ${ }^{2}$ Although individual circumstances differ across economies, recent trends suggest the potential for investment-led rebalancing along two dimensions. In some parts of the region, notably the ASEAN-4 countries, aggregate investment, particularly private fixed investment, appears low. In other parts, including the newly industrialized economies (NIEs) and Japan, although aggregate investment is in line with comparators, the composition is skewed toward exporters and capital-intensive firms, crowding out domestically focused and labor-intensive enterprises.

The analysis is guided by the following questions:

- What factors determine private investment spending at the aggregate level and at the sectoral level in Asia? What structural attributes help explain recent investment trends in the region? How do the patterns differ in Asia compared with other regions?

- Is investment in Asia constrained by the limited development of financial sectors and infrastructure in many countries?

- What policies could promote investment to rebalance Asian economies toward domestic demand-led growth and lift potential growth?

The analysis leads to two main findings. First, lower returns, greater uncertainty, and altered perceptions of the ease of doing business have held down investment in many regional economies over the past decade or so. But financial constraints also play a role, as small and medium enterprises (SMEs) and firms operating in the service sector appear to have limited access to external funding, including in Japan and the NIEs. In these economies, promoting financing on risk-based terms, supporting SMEs' restructuring through more private out-of-court workouts and streamlining tax policies could help rotate the composition of investment toward nontradable sectors. Second, shortfalls in

\footnotetext{
${ }^{1}$ This paper complements the IMF's April 2010 Regional Economic Outlook-Asia and Pacific, which examined the consumption aspects of rebalancing growth.

${ }^{2}$ Guimaraes and Unteroberdoerster (2006) also look at investment trends at the aggregate and firm level, focusing on developments in Malaysia since the Asian crisis.
} 
infrastructure also suppress private investment, particularly in the ASEAN-4. With most of the infrastructure in the region provided by governments, greater private participation through public-private partnerships and bond funds may help reduce the pressure on government budgets.

\section{INVESTMENT TRENDS IN ASIA}

\section{A. Recent Developments}

In the decade between the Asian crisis and the current global crisis, investment spending in Asia diverged across two groups of economies (Figure 1). In the economies with relatively large domestic demand bases-notably China and India-investment decreased slightly during the Asian crisis, but then increased appreciably starting in the early 2000 s. $^{3}$ In the group of relatively more export-oriented economies (NIEs, Japan, Malaysia, the Philippines, and Thailand), the average decline in the investment share of GDP following the Asian crisis was about

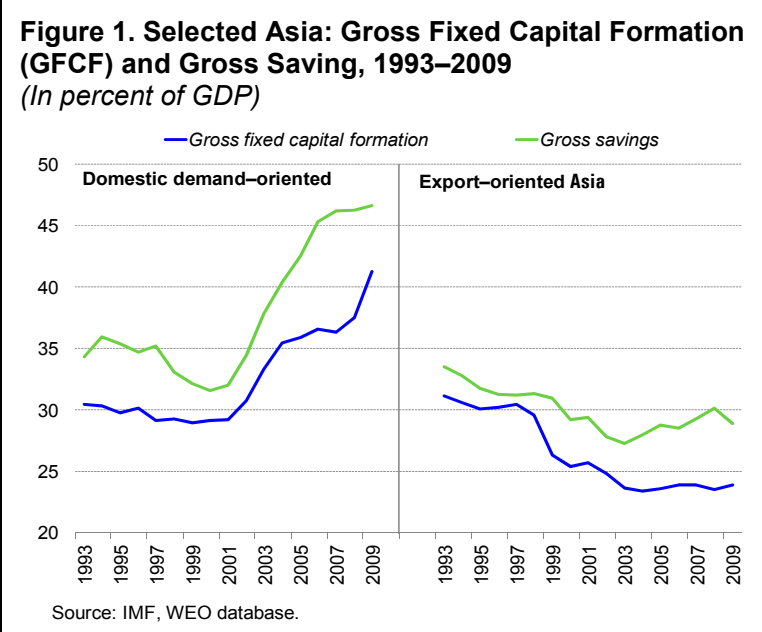

Figure 1. Selected Asia: Gross Fixed Capital Formation (GFCF) and Gross Saving, 1993-2009 (In percent of GDP)

7 percentage points. Combined with relatively stable saving in this group, the fall in investment as a share of GDP contributed to rising current account surpluses over this period.

A sharp fall in private spending on fixed capital explains most of the investment decline in export-oriented Asia (Figure 2). Outside of Taiwan Province of China, the bulk of the investment slowdown originated in the private sector. In particular, a sustained slump in fixed investment-in the form of factories and machinery-typically accounted for between half and three-fourths of the overall decline in countries for which a breakdown is available. In addition, excess investment in residential construction may have played some role in the precrisis boom and subsequent slump (Figure 3).

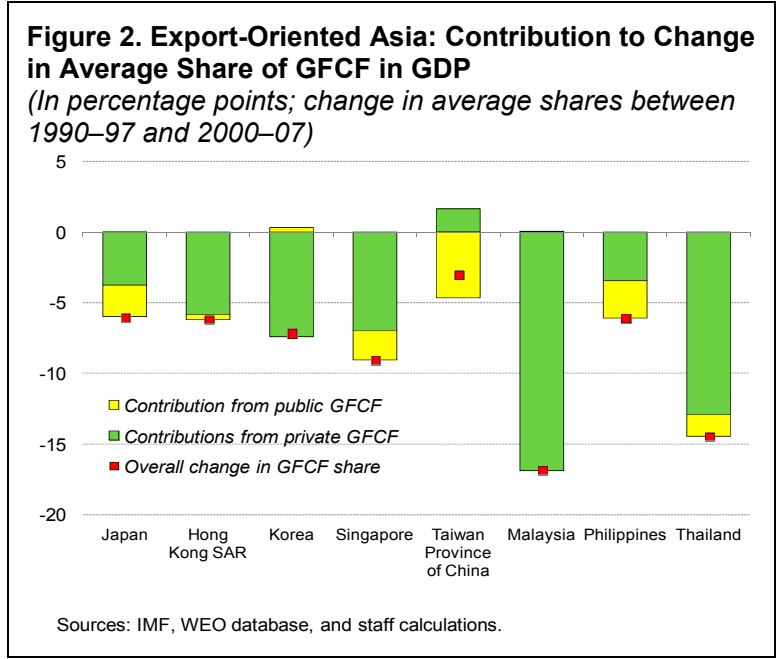

\footnotetext{
${ }^{3}$ Most of the subsequent discussion on private investment focuses on developments outside China and India, and emerging Asia is used to refer to economies excluding these two countries.
} 
Meanwhile, declining public investment has meant that an "infrastructure gap" persists between emerging Asia and the rest of the world, particularly in a few countries, such as the ASEAN-4 and India (Figures 4 and 5). The stock of infrastructure has increased since the 1990s along several dimensions, but still lags comparator emerging market regions in important respects. The median electricitygenerating capacity in emerging Asia is approximately 90 percent of the median for Latin America (up from 50 percent in 1995). And despite the rapid spread of telephones, particularly mobile phones, in the region in the past decade, emerging Asia also continues to lag behind Latin America in its stock of telecommunications infrastructure. There is growing recognition among policymakers in the region that these infrastructure deficits impede private investment and growth. ${ }^{4}$
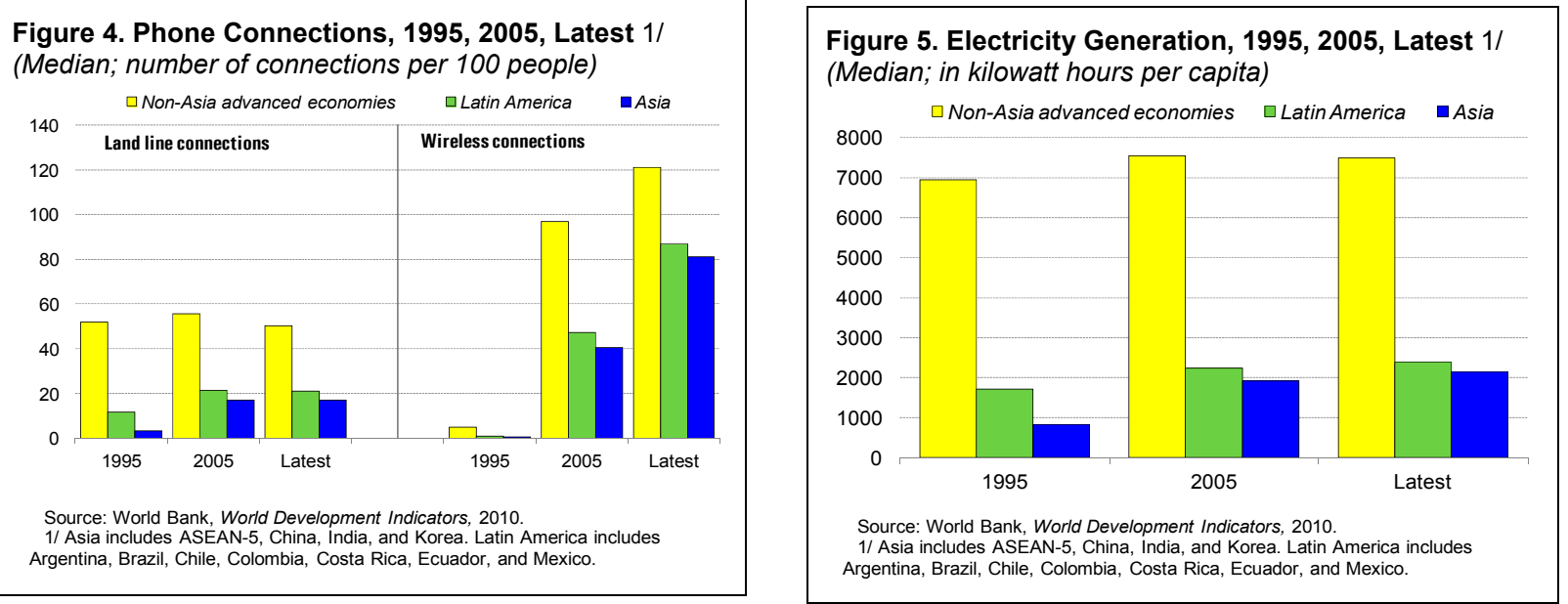

${ }^{4}$ India's National Economic Advisory Council, for example, has called the state of physical infrastructure a "binding constraint" on expansion and a "significant contributor to lower competitiveness" (Rangarajan, 2010). 


\section{B. Investment Levels and Composition in Asia}

Investment is relatively low in some regional economies, notably the ASEAN-4. Previous research using macro level estimates from a standard neoclassical growth model demonstrated that most ASEAN economies have been investing well below the rate implied by their current capital-output ratios (see Chapter III in the IMF's October 2010 Regional Economic Outlook-Asia and Pacific). Firm-level data also support this view. Even as liquidity indicators have improved and leverage has decreased since the Asian crisis, operating margins and investment have fallen markedly over this period (Table 1). Investment rates in the ASEAN-4 economies are now lower than in other emerging economies and closer to those in economies with much higher per capita incomes and capital intensity, such as Japan, the United States, and the euro area (Figure 6).

In contrast, in Japan and the NIEs, the issue is one of composition rather than the overall level of investment. In these economies, investment has shifted since the Asian crisis toward manufacturing and large firms, particularly in the export sector.

Therefore, even in cases where investment levels do not seem obviously low, there may be scope for supporting rebalancing by reorienting capital spending toward firms and sectors more directly linked to the domestic economy:

- In Japan, for instance, the share of the nonmanufacturing sector in overall investment has fallen from 70 percent in 2000 to just over 50 percent in 2007 (Figure 7). Despite broadly similar economic structures, this decline contrasts sharply with developments in comparator economies, such as

Table 1. Selected Financial Indicators for Firms 1990-97 and 2000-07

(Median)

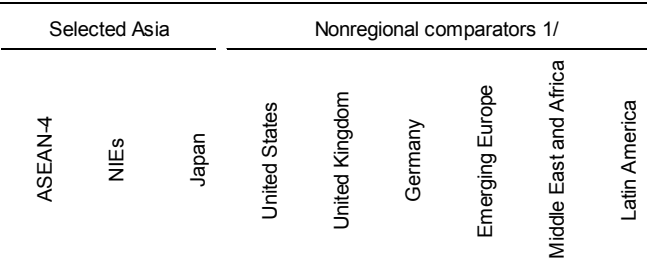

\begin{tabular}{|c|c|c|c|c|c|c|c|c|c|}
\hline \multicolumn{10}{|l|}{ Investment Rate } \\
\hline $1990-97$ & 0.19 & 0.17 & 0.14 & 0.15 & 0.14 & 0.18 & & & \\
\hline $2000-07$ & 0.10 & 0.11 & 0.09 & 0.12 & 0.11 & 0.11 & 0.16 & 0.15 & 0.12 \\
\hline \multicolumn{10}{|c|}{ Profitability (in percent) } \\
\hline \multicolumn{10}{|c|}{ Operating margins $2 /$} \\
\hline $1990-97$ & 11.14 & 7.14 & 4.16 & 7.17 & 6.56 & 0.33 & & & . \\
\hline $2000-07$ & 6.23 & 5.05 & 4.42 & 5.63 & 5.29 & 1.95 & 5.07 & 7.66 & 10.54 \\
\hline \multicolumn{10}{|l|}{ Valuation } \\
\hline \multicolumn{10}{|l|}{ Tobin's $Q$} \\
\hline 1990-97 & 3.35 & 2.76 & 2.98 & 3.11 & 2.38 & 2.06 & & & \\
\hline 2000-07 & 2.00 & 2.07 & 1.73 & 3.35 & 2.39 & 1.82 & 2.67 & 2.39 & 1.94 \\
\hline \multicolumn{10}{|l|}{ Liquidity } \\
\hline \multicolumn{10}{|c|}{ Current ratio $3 /$} \\
\hline 1990-97 & 1.25 & 1.27 & 1.36 & 1.93 & 1.35 & 1.75 & & & \\
\hline 2000-07 & 1.55 & 1.54 & 1.44 & 1.86 & 1.27 & 1.59 & 1.42 & 1.37 & 1.40 \\
\hline \multicolumn{10}{|l|}{ Capital intensity } \\
\hline \multicolumn{10}{|c|}{ Capital-labor ratio } \\
\hline 1990-97 & 43.63 & 94.52 & 163.09 & 38.23 & 20.55 & 42.23 & & & \\
\hline $2000-07$ & 31.66 & 68.16 & 113.38 & 57.88 & 32.46 & 58.53 & 46.23 & 24.98 & 76.48 \\
\hline \multicolumn{10}{|c|}{ Leverage (in percent) } \\
\hline \multicolumn{10}{|c|}{ Debt to equity } \\
\hline $1990-97$ & 66.63 & 63.13 & 88.57 & 49.49 & 38.46 & 55.60 & $\ldots$ & & .. \\
\hline $2000-07$ & 43.59 & 41.13 & 42.49 & 41.02 & 39.85 & 51.14 & 29.67 & 42.08 & 50.72 \\
\hline \multicolumn{10}{|c|}{ Short-term debt to total debt } \\
\hline $1990-97$ & 68.48 & 56.73 & 47.52 & 14.96 & 48.41 & 48.33 & & $\ldots$ & $\ldots$ \\
\hline $2000-07$ & 65.05 & 68.00 & 59.02 & 13.88 & 35.21 & 41.07 & 63.58 & 45.85 & 38.59 \\
\hline \multicolumn{10}{|c|}{ Sources: Worldscope; and IMF staff calculations. } \\
\hline \multicolumn{10}{|c|}{$\begin{array}{l}\text { 1/ Emerging Europe includes Czech Republic, Hungary, Poland, Russia, and Turkey. } \\
\text { Middle East and Africa includes Israel, Egypt, Morocco, Pakistan, and South Africa. Latin } \\
\text { America includes Argentina, Brazil, Chile, Colombia, Mexico, and Peru. } \\
\text { 2/ Operating earnings (EBIT) in percent of sales. } \\
\text { 3/ Current assets to current liabilities. }\end{array}$} \\
\hline
\end{tabular}

Figure 6. Firm-Level Investment Rate, 2000-07 1/ (Median investment-to-capital ratio)

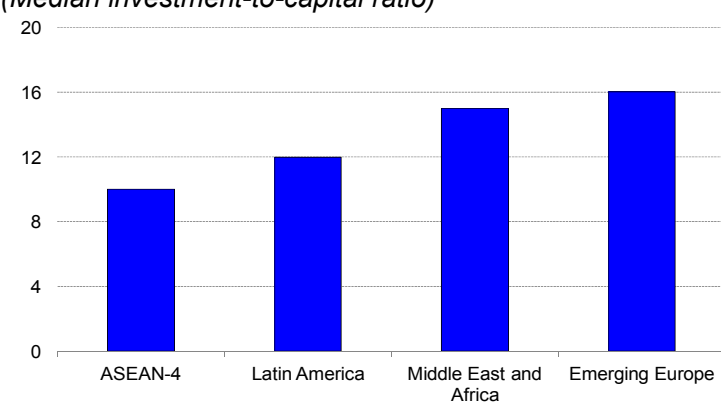

Sources: Worldscope; and IMF staff calculations.

1/ Latin America includes Argentina, Brazil, Chile, Colombia, Mexico, and Peru. Middle East and Africa includes Israel, Egypt, Morocco, Pakistan, and South Africa. Emerging Europe includes Czech Republic, Hungary, Poland, Russia, and Turkey. 
the United States, the United Kingdom, and Germany, where the starting share was similar but has now risen to about 80 percent. In particular, the share in total investment of the four main exporting sectors-automobiles, machinery, electronics, and steel一rose from 19 percent to 31 percent in Japan.

- $\quad$ At the same time, investment has lagged behind for smaller firms and in the services sector (Figure 8). These divergent trends are clearly highlighted in Korea, where rising regional competition has put pressure on labor-intensive SMEs, particularly in low-end manufacturing. ${ }^{5}$ In addition, SMEs seem to suffer from excess capacity, while low productivity in the services sector, where many of these firms operate, has also been a constraint on investment.
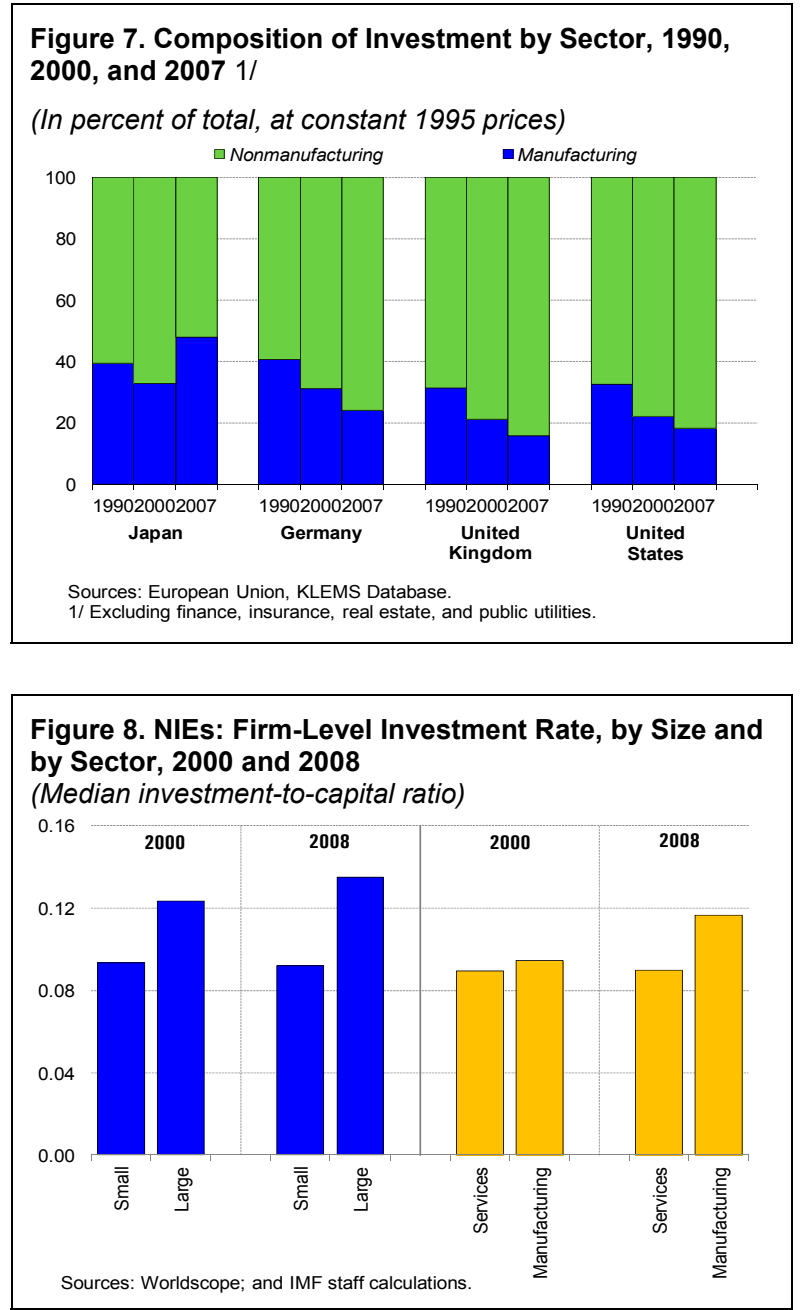

\section{What Drives InVESTMENT IN ASIA?}

The two key aspects of investment in Asia - the fall in the share of investment in GDP in some economies and the shift in composition in others-are at the core of the rebalancing debate. This section attempts to explain both features of the data with a view to establishing what specific policies might help on the Asian side of the global rebalancing effort.

\section{A. Explaining the Fall in Aggregate Investment}

Could the fall in the private investment simply reflect a decline in the relative price of capital goods? Following the Asian crisis, several economies introduced structural and financial

\footnotetext{
${ }^{5}$ Country-specific experiences vary, but the rise of China has intensified competitive pressures, particularly on the SMEs in the region. In the case of Korea, for example, SMEs have either scaled down operations or shifted production to China (Kang and Kim, 2006). The sectors most directly affected appear to be textiles and basic manufacturing.
} 
market reforms that may have raised their efficiency in producing capital goods. ${ }^{6}$ Another question is whether, as the importance of IT capital has increased, the productivity gains in that sector have contributed to a decline in the relative price of capital (DeLong, 2002). In such a case, the decline in the share of nominal investment spending in nominal GDP may simply reflect a fall in the relative price of capital goods.

On balance, however, the evidence suggests that falling relative prices are unlikely to explain the decline in the investment rate. If that explanation were valid, we would expect to see a strong positive correlation between the change in the relative price of capital and the change in the investment share of GDP. ${ }^{7}$ However, the evidence suggests that in Asia the opposite is true (Figure 9). In fact, the relative price of capital and the investment rate appear to be negatively correlated. The decline in the investment share was associated with lower relative prices in only

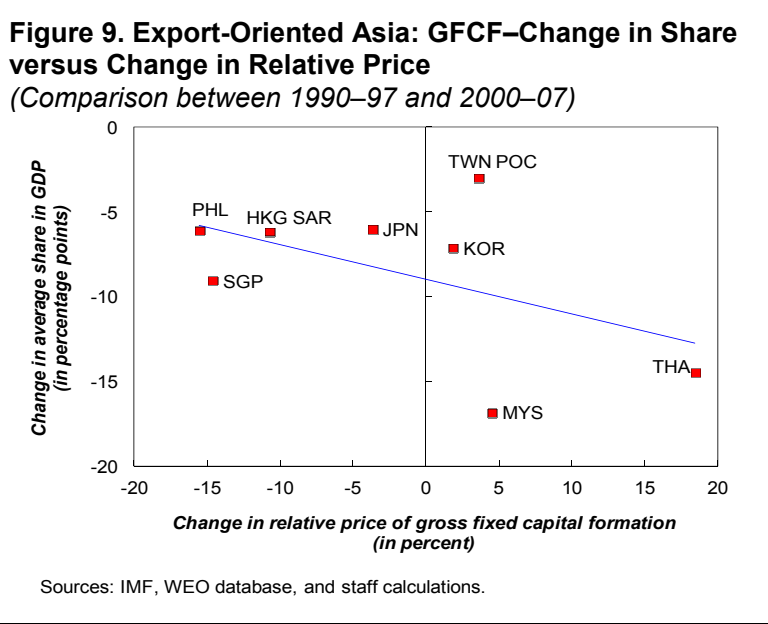
half the cases, possibly reflecting the differential pace of structural and financial reforms across regional economies or, alternatively, compositional differences in the mix of IT and non-IT capital goods employed. Moreover, the economies that have witnessed the largest falls in the investment share of GDP have also seen the largest increases in the relative price of capital goods. And there is considerable variation across the region: Hong Kong SAR, Japan, and Singapore all experienced a similar decline in the investment share but differing declines in the relative price of capital goods. At the very least, this explanation cannot account for trends across the region as a whole

Instead, as discussed below, estimates from a standard regression approach suggest that at the aggregate level, the decline in the investment rate may have been caused by structural changes following the Asian crisis (Table 2).

\section{Empirical Strategy}

The investment rate is modeled as a function of its own lagged value to capture persistence and a set of controls - (i) GDP growth as a proxy for the aggregate return on investment; (ii) the standard deviation of GDP growth over rolling four-year windows to capture

\footnotetext{
${ }^{6}$ More generally, Hsieh and Klenow (2007) document an inverse relationship between the relative price of capital goods and the level of development. This implies that as economies grow the relative price of capital falls over time as they become more efficient at producing capital goods.

${ }^{7}$ The relative price of capital is measured using the ratio of the investment deflator to the overall GDP deflator from the IMF's World Economic Outlook database.
} 
macroeconomic uncertainty; (iii) the real interest rate; (iv) the manufacturing share of value added; (v) an index of financial market development; and (vi) a measure of the ease of doing business (or the perceived investment climate)—along with country-specific, time-invariant fixed effects. ${ }^{8}$ Specifically, the following equation is estimated

$\left(\frac{I}{Y}\right)_{j, t}=\gamma_{j}+\beta_{1}\left(\frac{I}{Y}\right)_{j, t-1}+\beta_{2} X_{j, t}+$ $\epsilon_{j, t}$

where the investment rate in country $j$ in year $t$ is modeled as a function of its lagged value $\left(\frac{I}{Y}\right)_{j, t-1}, X_{j, t}$ is a vector of controls, and $\gamma_{j}$ is the country-specific fixed effect. The regression framework used is Arellano-Bond GMM estimation, which allows for the inclusion of the lagged dependent variable along with other factors that drive investment.
Table 2. Determinants of Private Investment Spending 1/

\begin{tabular}{|c|c|c|c|c|c|}
\hline Lagged private investment & $\begin{array}{l}0.772 \text { *** } \\
(0.039)\end{array}$ & $\begin{array}{l}0.7422^{* * *} \\
(0.040)\end{array}$ & $\begin{array}{l}0.748^{* * *} \\
(0.040)\end{array}$ & $\begin{array}{l}0.745^{* * *} \\
(0.045)\end{array}$ & $\begin{array}{l}0.710^{* * *} \\
(0.036)\end{array}$ \\
\hline Real interest rate & $\begin{array}{l}0.032 \text { * } \\
(0.017)\end{array}$ & $\begin{array}{l}0.030^{*} \\
(0.018)\end{array}$ & $\begin{array}{l}0.033 \text { * } \\
(0.017)\end{array}$ & $\begin{array}{r}0.014 \\
(0.011)\end{array}$ & $\begin{array}{r}0.006 \\
(0.011)\end{array}$ \\
\hline GDP growth & $\begin{array}{l}0.360^{* * *} \\
(0.046)\end{array}$ & $\begin{array}{l}0.328^{* * *} \\
(0.040)\end{array}$ & $\begin{array}{l}0.340^{* * *} \\
(0.039)\end{array}$ & $\begin{array}{l}0.331^{* * *} \\
(0.040)\end{array}$ & $\begin{array}{l}0.299 \text { *** } \\
(0.041)\end{array}$ \\
\hline Volatility & & $\begin{array}{l}-0.224 \\
(0.060)\end{array}$ & $\begin{array}{l}-0.241^{* * *} \\
(0.060)\end{array}$ & $\begin{array}{l}-0.250^{* * *} \\
(0.064)\end{array}$ & $\begin{array}{l}-0.310^{* * *} \\
(0.077)\end{array}$ \\
\hline $\begin{array}{l}\text { Manufacturing share of value } \\
\text { added }\end{array}$ & & & $\begin{array}{r}0.091 \\
(0.072)\end{array}$ & $\begin{array}{r}0.054 \\
(0.063)\end{array}$ & $\begin{array}{r}0.089 \\
(0.062)\end{array}$ \\
\hline Ease of doing business & & & & $\begin{array}{r}0.244 \\
(0.157)\end{array}$ & $\begin{array}{l}0.343 \text { ** } \\
(0.174)\end{array}$ \\
\hline Financial development & & & & & $\begin{array}{l}21.270^{*} \\
(12.210)\end{array}$ \\
\hline $\begin{array}{l}\text { Financial development } \\
\text { (squared) }\end{array}$ & & & & & $\begin{array}{c}-15.210 * \\
(9.228)\end{array}$ \\
\hline Observations & 412 & 412 & 369 & 338 & 260 \\
\hline Number of countries & 44 & 44 & 42 & 39 & 37 \\
\hline $\begin{array}{l}\text { Autocorrelation in first- } \\
\text { differenced errors (p-value) 2l }\end{array}$ & 0.878 & 0.926 & 0.938 & 0.671 & 0.339 \\
\hline \multicolumn{6}{|l|}{ Source: IMF staff estimates. } \\
\hline \multicolumn{6}{|c|}{$\begin{array}{l}\text { 1/ Dependent variable: private investment-to-GDP ratio. Arellano-Bond estimation } \\
\text { technique used. Robust standard errors in parentheses. }{ }^{* *},{ }^{* *} \text {, and }{ }^{*} \text { indicate significance } \\
\text { at } 1,5 \text {, and } 10 \text { percent levels, respectively. }\end{array}$} \\
\hline
\end{tabular}

Results

Across a large cross-country panel of emerging and advanced economies over the period 1998-2009, the approach identifies the following key determinants:

- The aggregate return on investment (average growth) is positively associated with investment spending. Following the Asian crisis, average real GDP growth in emerging Asia (excluding China and India) slowed appreciably, reducing investment spending by $2 \frac{1}{2}$ percentage points of GDP on average.

- Macroeconomic uncertainty (volatility) is negatively correlated with investment spending. As uncertainty rises, firms hold back on costly and potentially irreversible investment since they prefer the option value of waiting until the uncertainty clears. Growth in emerging Asia has been relatively more volatile as the recovery

\footnotetext{
${ }^{8}$ The index of financial development (Abiad, Detragiache, and Tressel, 2008) is a normalized average across seven indicators (banking supervision, privatization, entry barriers, directed credit, credit ceilings, interest rate controls, and securities market reform). The measure of ease of doing business is based on an index compiled by the International Country Risk Guide (www.prsgroup.com/ICRG.aspx) and largely reflects perceptions of corruption in the private and public sectors.
} 
from the 1997-98 downturn gave way to the tech boom-and-bust cycle, followed by a period of solid growth that, in turn, ended sharply with the current crisis. This higher volatility over the past decade has depressed investment spending in the region by approximately 1 percentage point of GDP.

- A surprising deterioration in investors' perceptions of the business climate has also dampened investment. The altered perceptions are associated with a further decline in investment spending of three-quarters of a percentage point of GDP over the past decade.

Interestingly, once the main structural determinants of investment are controlled for, exchange rates do not appear to have a major impact on aggregate investment rates. Table 3 reports results from regressions similar to the ones estimated above, using three different exchange rate indices from the IMF's INS database: an index of the nominal exchange rate (USD per NCU), the nominal effective exchange rate (NEER), and the real effective exchange rate (REER). For each index, the interaction with a dummy variable for Asia (covering eleven economies - China, Japan, Hong Kong SAR, India, Indonesia, Korea, Malaysia, the Philippines, Singapore, Taiwan Province of China, and Thailand) is also reported. As seen in Table 3, none of the exchange rate indices has a significant effect for the sample as a whole, nor is there an

\begin{tabular}{|c|c|c|c|c|c|c|}
\hline \multirow[b]{2}{*}{ Lagged Private Investment } & \multicolumn{2}{|c|}{ USD/NCU } & \multicolumn{2}{|c|}{ NEER } & \multicolumn{2}{|c|}{ REER } \\
\hline & $\begin{array}{l}0.739^{* * *} \\
(0.0405)\end{array}$ & $\begin{array}{l}0.735^{\star * *} \\
(0.0421)\end{array}$ & $\begin{array}{l}0.739^{* * *} \\
(0.0391)\end{array}$ & $\begin{array}{l}0.735^{* * *} \\
(0.0391)\end{array}$ & $\begin{array}{l}0.738^{* * *} \\
(0.0405)\end{array}$ & $\begin{array}{l}0.731^{* * *} \\
(0.0415)\end{array}$ \\
\hline Real Interest Rate & $\begin{array}{c}0.0302 \\
(0.0196)\end{array}$ & $\begin{array}{c}0.0281 \\
(0.0196)\end{array}$ & $\begin{array}{l}0.0316 \\
(0.0198)\end{array}$ & $\begin{array}{c}0.0303 \\
(0.0198)\end{array}$ & $\begin{array}{c}0.0282 \\
(0.0191)\end{array}$ & $\begin{array}{c}0.0272 \\
(0.0194)\end{array}$ \\
\hline Growth Rate of GDP & $\begin{array}{l}0.335^{\star * *} \\
(0.0376)\end{array}$ & $\begin{array}{l}0.329^{* * *} \\
(0.0356)\end{array}$ & $\begin{array}{l}0.328^{* * *} \\
(0.0389)\end{array}$ & $\begin{array}{l}0.325^{\star * *} \\
(0.0375)\end{array}$ & $\begin{array}{l}0.329^{* * *} \\
(0.0404)\end{array}$ & $\begin{array}{l}0.327^{\star * *} \\
(0.0398)\end{array}$ \\
\hline Volatility & $\begin{array}{l}-0.224^{* * *} \\
(0.0587)\end{array}$ & $\begin{array}{l}-0.214^{* * *} \\
(0.0567)\end{array}$ & $\begin{array}{l}-0.224^{* * *} \\
(0.0599)\end{array}$ & $\begin{array}{l}-0.226^{* * *} \\
(0.0607)\end{array}$ & $\begin{array}{l}-0.220^{* * *} \\
(0.0577)\end{array}$ & $\begin{array}{l}-0.218^{* * *} \\
(0.0581)\end{array}$ \\
\hline Exchange Rate Index & $\begin{array}{l}0.00246 \\
(0.00500)\end{array}$ & $\begin{array}{l}0.00180 \\
(0.00485)\end{array}$ & $\begin{array}{l}-0.000368 \\
(0.00629)\end{array}$ & $\begin{array}{r}-0.000735 \\
(0.00619)\end{array}$ & $\begin{array}{l}0.00398 \\
(0.00748)\end{array}$ & $\begin{array}{r}0.00228 \\
(0.00691)\end{array}$ \\
\hline Asia*Exchange Rate Index & & $\begin{array}{c}0.0158 \\
(0.0289)\end{array}$ & & $\begin{array}{c}0.0124 \\
(0.0235)\end{array}$ & & $\begin{array}{c}0.0220 \\
(0.0351)\end{array}$ \\
\hline Observations & 412 & 412 & 412 & 412 & 412 & 412 \\
\hline Number of Countries & 44 & 44 & 44 & 44 & 44 & 44 \\
\hline $\begin{array}{l}\text { Test for autocorrelation in first- } \\
\text { differenced errors ( } p \text {-value) } 2 /\end{array}$ & 0.9107 & 0.8912 & 0.9288 & 0.9241 & 0.9199 & 0.9159 \\
\hline $\begin{array}{l}\text { Source: IMF staff estimates } \\
\text { 1/ Dependent variable: private In } \\
\text { used. Alternative exchange rate } \\
\text { 2/ Arellano Bond test of no secc }\end{array}$ & $\begin{array}{l}\text { stment-to } \\
\text { dices as li } \\
\text { order au }\end{array}$ & $\begin{array}{l}\text {-GDP ratio. } \\
\text { isted in colu } \\
\text { tocorrelatio }\end{array}$ & $\begin{array}{l}\text { llano Bo } \\
\text { headers } \\
\text { first-diffe }\end{array}$ & $\begin{array}{l}\text { stimation } t \\
\text { bust stand } \\
\text { ced errors. }\end{array}$ & $\begin{array}{l}\text { technique } \\
\text { dard errors }\end{array}$ & \\
\hline
\end{tabular}
Asia-specific significant effect. ${ }^{9}$

The empirical analysis also suggests that infrastructure weaknesses may be constraining investment in Asia (Table 4). Increases in the stock of infrastructure can boost investment through several channels. Improved connectivity (better roads, bridges, and telecommunications) will reduce transport and communication costs, facilitate internal specialization, and allow for an improved division of labor within the country. Furthermore,

\footnotetext{
${ }^{9}$ Since the dummy variable is time-invariant, it is not possible to include it in the regression along with country fixed effects.
} 
the decline in transportation costs can support clustering of industries, with attendant gains in productivity that raise the return on investment through knowledge spillovers and agglomeration effects (Krugman, 1991 and Venables, 2006). This is particularly important for countries such as India, Indonesia, and China, where vast distances separate potential producers and end users. Power and energy infrastructure that minimizes work stoppages and disruptions in production and distribution can also augment returns on investment by raising productivity. In addition, better roads, electricity, and water supply can enhance health and education investments, reducing inequality and raising the human capital of the work force. $^{10}$

\begin{tabular}{|c|c|c|c|c|}
\hline Lagged private investment & $\begin{array}{l}0.7011^{* * *} \\
(0.050)\end{array}$ & $\begin{array}{l}0.7411^{* * *} \\
(0.054)\end{array}$ & $\begin{array}{l}0.673^{* * *} \\
(0.046)\end{array}$ & $\begin{array}{l}0.422 \text { *** } \\
(0.081)\end{array}$ \\
\hline Real interest rate & $\begin{array}{l}-0.026 \\
(0.024)\end{array}$ & $\begin{array}{r}0.006 \\
(0.026)\end{array}$ & $\begin{array}{r}0.018 \\
(0.021)\end{array}$ & $\begin{array}{l}-0.038 \\
(0.027)\end{array}$ \\
\hline Growth rate of GDP & $\begin{array}{l}0.2444^{* * *} \\
(0.049)\end{array}$ & $\begin{array}{l}0.285^{* * *} \\
(0.050)\end{array}$ & $\begin{array}{l}0.228^{* * *} \\
(0.042)\end{array}$ & $\begin{array}{l}0.153 \text { ** } \\
(0.077)\end{array}$ \\
\hline Volatility & $\begin{array}{l}-0.104 \text { * } \\
(0.057)\end{array}$ & $\begin{array}{l}-0.164 \text { *** } \\
(0.048)\end{array}$ & $\begin{array}{l}-0.032 \\
(0.044)\end{array}$ & $\begin{array}{l}-0.345^{* * *} \\
(0.108)\end{array}$ \\
\hline Electricity & $\begin{array}{l}2.204^{* *} \\
(1.122)\end{array}$ & & & \\
\hline Telephones & & $\begin{array}{l}1.420 \text { ** } \\
(0.592)\end{array}$ & & \\
\hline Cell phones & & & $\begin{array}{l}0.689^{* * *} \\
(0.186)\end{array}$ & \\
\hline Roads & & & & $\begin{array}{l}4.015^{* * *} \\
(1.236)\end{array}$ \\
\hline Observations & 316 & 325 & 325 & 120 \\
\hline Number of countries & 41 & 42 & 42 & 32 \\
\hline $\begin{array}{l}\text { Autocorrelation in first- } \\
\text { differenced errors (p-value) } 2 /\end{array}$ & 0.347 & 0.758 & 0.72 & 0.267 \\
\hline \multicolumn{5}{|l|}{ Source: IMF staff estimates. } \\
\hline $\begin{array}{l}\text { 1/ Dependent variable: private } \\
\text { technique used. Robust standar } \\
\text { significance at } 1,5 \text {, and } 10 \text { perc } \\
2 / \text { Arellano-Bond test of no se } \\
\text { errors. }\end{array}$ & $\begin{array}{l}\text { nvestment-to- } \\
\text { errors in pare } \\
\text { nt levels, resp } \\
\text { ond-order aut }\end{array}$ & $\begin{array}{l}\text { GDP ratio. A } \\
\text { ntheses.***, } \\
\text { ectively. } \\
\text { correlation }\end{array}$ & $\begin{array}{l}\text { llano-Bond e } \\
\text {, and *indica } \\
\text { first-differenc }\end{array}$ & $\begin{array}{l}\text { stimation } \\
\text { te } \\
\text { ed }\end{array}$ \\
\hline
\end{tabular}

Empirically, improvements in infrastructure appear to have a powerful impact on private investment spending in the region. Across four commonly used indicators of infrastructure (electricity generation, telephone lines, cell phone subscribers, and road length), there is strong evidence of a positive association with private investment spending. ${ }^{11}$ Estimates from a simple regression framework as outlined above suggest that electricity and roads have the strongest impact on private investment, while increases in the number of telephone lines and cell phone subscribers are also positively associated with higher private investment. ${ }^{12}$

\footnotetext{
${ }^{10}$ Calderon and Serven (2004a, 2004b) point out that improvements in infrastructure are associated with reduced inequality and higher growth. But there may still be an equity-efficiency trade-off in the short term when current needs in the education and health sectors must be weighed against the requirements for infrastructure.

${ }^{11}$ These physical stocks of infrastructure do not adjust for quality differences across countries, but are preferable as indicators of infrastructure services to expenditure-based measures, which often capture other categories of spending (Pritchett, 1996).

${ }^{12}$ Greater use of telephones (particularly mobile phones) is increasingly seen as an important facilitator of business activities. For an example of how the spread of mobile telephones has enhanced price discovery, eliminated waste, and enhanced efficiency in a specific industry, see Jensen (2007) on the impact of cell phones on the fisheries industry in Kerala, India.
} 


\section{B. Why Has the Composition of Investment Changed?}

What explains the shift in investment away from services and small firms in more developed parts of the region since the Asian crisis? In this section, firm-level panel data is used to help answer this question.

\section{Empirical Strategy}

The data includes all listed nonfinancial firms in our selected jurisdictions covered in the Worldscope database during the period 1989-2008. The Worldscope database is well known for its standardized presentation of global investment portfolios and its good coverage of historical data. The database covers more than 96 percent of the world's market value represented by it. One important advantage of using the database is that it provides standardized data for countries with different reporting practices, yielding relatively more reliable cross-country comparisons. Several firms entered the data set after 1995, implying somewhat shorter series for them. Outliers were excluded from the analysis based on standard criteria.

The data is used to estimate the standard neoclassical investment model, which relates current investment to expectations of future profitability through Tobin's $Q$ ratio, defined as the ratio of the stock market valuation of the firm to the replacement cost of its capital stock. Incorporating the standard adjustments for debt, Tobin's $Q$ is defined as:

$$
Q_{i t}=\left[\frac{V_{i t}+B_{i t}-C_{i t}}{p_{t}(1-\delta) K_{i, t-1}}\right],
$$

where $V$ is the firm's fundamental value or the expected present discounted value of future payments to shareholders; $B$ is the book value of its outstanding debt; $C$ is current assets; $p$ is the price of the investment good; $\delta$ is the capital depreciation rate (assumed to equal 8 percent); and $K$ is the replacement value of the firm's capital stock. The capital stock measure was estimated using the standard perpetual inventory method, with the net book value of plant, property, and equipment treated as the starting value and subsequent values determined using data on investment, disposals, and acquisitions.

The firm-level panel data was used to estimate the standard neoclassical investment model, which relates current investment to expectations of future profitability through Tobin's $Q$ ratio, augmented by additional factors. The model estimated can be expressed as follows:

$$
\Delta\left(\frac{I}{K}\right)_{i t}=c_{t}+b \Delta Q_{i t}+c \Delta Z_{i, t}+\Delta \varepsilon_{i t}
$$

where $I / K$ is the investment rate, $Q$ is Tobin's $Q,{ }^{13}$ and $Z$ is a vector of additional variables.

${ }^{13}$ Defined as the ratio of the stock market valuation of the firm to the replacement cost of its capital stock. 
The model is estimated augmented by additional regressors, including (1) cash flow, which measures the internal funds available to finance investment projects and is typically used in the literature as a proxy for financing constraints; (2) leverage, measured by the debt-to-assets ratio, as a proxy for the effect of financial restructuring on investment; and (3) the standard deviation of returns on the weekly stock price index to capture the potential negative impact of uncertainty on investment. The model is estimated using a GMM approach to allow for endogeneity and measurement error in the dependent variables. Estimation was in first-differences and included year dummies, to control for firm- and time-specific effects. This approach yields consistent estimates provided there is no higher-order serial correlation in the residuals and the instruments are valid. ${ }^{14}$ Diagnostic tests were used to verify these conditions. ${ }^{15}$

\section{Results}

In recent years, several factors appear to have been inhibiting investment by domestically oriented firms. In the period before the Asian crisis, the firm-level relationship between investment and fundamentals was relatively weak, lending support to the hypothesis of overinvestment. In the post-crisis period, however, a much stronger link has emerged, with the relative importance of different factors varying based on firm characteristics (Table 5):

- $\quad$ Expectations of future profitability are significant drivers of investment spending for most firms in the NIEs and, to a lesser extent in Japan. In these economies, relatively lower returns on investment by small firms and in the service sector may be contributing to the unbalanced composition of investment.

- In the NIEs and in Japan, inadequate access to external finance is a binding constraint on investment for small and domestically oriented firms. Despite significant progress in financial restructuring since the Asian crisis, a legacy of excess leverage and dependence on debt financing continues to hold back investment for some firms (Figure 10). By necessitating repayments regardless of profitability, excessive debt financing

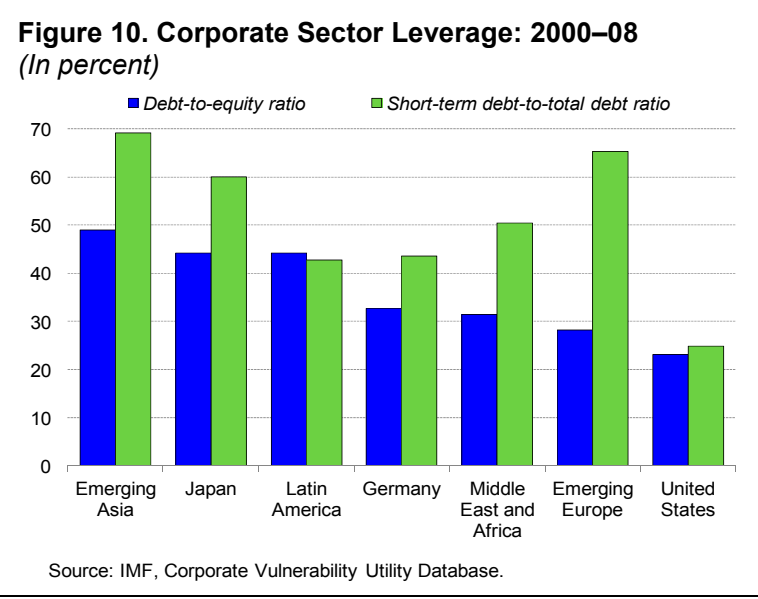
can retard investment, particularly in longer-term and more risky projects.

\footnotetext{
${ }^{14}$ The instruments reported are lagged values of the dependent variable and our regressors, but results were robust to using alternative instrument sets.

${ }^{15}$ The models were assessed based on tests for serial correlation ( $\mathrm{m} 1$ and $\mathrm{m} 2$ ) and instrument validity (Hansen).
} 
Table 5. Asia: Investment Equations 1/, 2/

\begin{tabular}{|c|c|c|c|c|c|c|c|c|c|c|}
\hline \multirow{2}{*}{ ASEAN-4 } & \multicolumn{2}{|c|}{ Time period } & \multicolumn{2}{|c|}{ Size } & \multicolumn{2}{|c|}{ Market exposure } & \multicolumn{2}{|c|}{ Capital intensity } & \multicolumn{2}{|c|}{ Sector } \\
\hline & Precrisis & Postcrisis & Big & Small & Foreign & Domestic & High & Low & Manufacturing & Services \\
\hline Tobin's $Q$ & $\begin{array}{l}0.027^{* *} \\
(0.01)\end{array}$ & $\begin{array}{l}0.004 \\
(0.01)\end{array}$ & $\begin{array}{l}0.011 \text { ** } \\
(0.01)\end{array}$ & $\begin{array}{l}0.002 \\
(0.02)\end{array}$ & $\begin{array}{l}0.006 \\
(0.01)\end{array}$ & $\begin{array}{l}0.015 \\
(0.01)\end{array}$ & $\begin{array}{l}0.013^{* *} \\
(0.01)\end{array}$ & $\begin{array}{l}0.019^{* *} \\
(0.01)\end{array}$ & $\begin{array}{l}0.006 \\
(0.01)\end{array}$ & $\begin{array}{l}0.010 \\
(0.01)\end{array}$ \\
\hline Liquidity $3 /$ & $\begin{array}{r}-0.093 \\
(0.09)\end{array}$ & $\begin{array}{l}0.161 \text { ** } \\
(0.08)\end{array}$ & $\begin{array}{r}-0.003 \\
(0.05)\end{array}$ & $\begin{array}{l}0.169 \text { ** } \\
(0.08)\end{array}$ & $\begin{array}{r}-0.019 \\
(0.03)\end{array}$ & $\begin{array}{l}0.103 * \\
(0.06)\end{array}$ & $\begin{array}{l}0.077^{* *} \\
(0.04)\end{array}$ & $\begin{array}{r}-0.033 \\
(0.09)\end{array}$ & $\begin{array}{r}-0.052 \\
(0.05)\end{array}$ & $\begin{array}{l}0.115^{* *} \\
(0.05)\end{array}$ \\
\hline Leverage 4 / & $\begin{array}{l}0.002 \\
(0.00)\end{array}$ & $\begin{array}{r}-0.000 \\
(0.00)\end{array}$ & $\begin{array}{l}-0.003^{* *} \\
(0.00)\end{array}$ & $\begin{array}{l}0.001 \\
(0.00)\end{array}$ & $\begin{array}{l}-0.002 \text { ** } \\
(0.00)\end{array}$ & $\begin{array}{r}-0.001 \\
(0.00)\end{array}$ & $\begin{array}{r}-0.000 \\
(0.00)\end{array}$ & $\begin{array}{r}-0.000 \\
(0.00)\end{array}$ & $\begin{array}{l}-0.002^{* *} \\
(0.00)\end{array}$ & $\begin{array}{l}0.000 \\
(0.00)\end{array}$ \\
\hline \multirow[t]{2}{*}{ Uncertainty $5 /$} & $\begin{array}{l}0.203 \\
(0.13)\end{array}$ & $\begin{array}{l}-0.139 \text { ** } \\
(0.07)\end{array}$ & $\begin{array}{r}-0.034 \\
(0.07)\end{array}$ & $\begin{array}{l}0.065 \\
(0.08)\end{array}$ & $\begin{array}{l}-0.119 \text { ** } \\
(0.04)\end{array}$ & $\begin{array}{r}-0.050 \\
(0.07)\end{array}$ & $\begin{array}{l}-0.138 \text { ** } \\
(0.06)\end{array}$ & $\begin{array}{l}0.081 \\
(0.06)\end{array}$ & $\begin{array}{c}-0.083 \text { * } \\
(0.05)\end{array}$ & $\begin{array}{l}0.022 \\
(0.07)\end{array}$ \\
\hline & \multicolumn{10}{|c|}{$\mathrm{p}$-value of specification tests } \\
\hline $\begin{array}{l}\text { m1 } \\
\text { m2 } \\
\text { Hansen-test }\end{array}$ & $\begin{array}{l}0.032 \\
0.269 \\
0.116\end{array}$ & $\begin{array}{l}0.000 \\
0.199 \\
0.735\end{array}$ & $\begin{array}{l}0.000 \\
0.836 \\
0.112\end{array}$ & $\begin{array}{l}0.001 \\
0.454 \\
0.409\end{array}$ & $\begin{array}{l}0.000 \\
0.839 \\
0.077\end{array}$ & $\begin{array}{l}0.000 \\
0.995 \\
0.120\end{array}$ & $\begin{array}{l}0.000 \\
0.708 \\
0.297\end{array}$ & $\begin{array}{l}0.005 \\
0.895 \\
0.540\end{array}$ & $\begin{array}{l}0.000 \\
0.548 \\
0.201\end{array}$ & $\begin{array}{l}0.000 \\
0.633 \\
0.385\end{array}$ \\
\hline $\begin{array}{l}\text { Number of firms } \\
\text { Number of observation }\end{array}$ & $\begin{array}{r}389 \\
1040\end{array}$ & $\begin{array}{l}1375 \\
6441\end{array}$ & $\begin{array}{r}753 \\
3572\end{array}$ & $\begin{array}{r}809 \\
3447\end{array}$ & $\begin{array}{r}654 \\
3884\end{array}$ & $\begin{array}{r}851 \\
3597\end{array}$ & $\begin{array}{l}1129 \\
3838\end{array}$ & $\begin{array}{r}556 \\
1740\end{array}$ & $\begin{array}{r}901 \\
4590\end{array}$ & $\begin{array}{r}604 \\
2891\end{array}$ \\
\hline \multirow{2}{*}{ NIEs } & \multicolumn{2}{|c|}{ Time period } & \multicolumn{2}{|c|}{ Size } & \multicolumn{2}{|c|}{ Market exposure } & \multicolumn{2}{|c|}{ Capital intensity } & \multicolumn{2}{|c|}{ Sector } \\
\hline & Precrisis & Postcrisis & Big & Small & Foreign & Domestic & High & Low & Manufacturing & Services \\
\hline Tobin's $Q$ & $\begin{array}{l}0.005 \\
(0.01)\end{array}$ & $\begin{array}{l}0.010^{* *} \\
(0.01)\end{array}$ & $\begin{array}{l}0.018 \text { ** } \\
(0.01)\end{array}$ & $\begin{array}{l}0.010^{* *} \\
(0.00)\end{array}$ & $\begin{array}{l}0.015^{* *} \\
(0.00)\end{array}$ & $\begin{array}{l}0.007 \\
(0.01)\end{array}$ & $\begin{array}{l}0.017^{* *} \\
(0.01)\end{array}$ & $\begin{array}{l}0.008 \text { * } \\
(0.01)\end{array}$ & $\begin{array}{l}0.019 \text { ** } \\
(0.00)\end{array}$ & $\begin{array}{l}0.010 \\
(0.00)\end{array}$ \\
\hline Liquidity $3 /$ & $\begin{array}{l}0.171 \\
(0.14)\end{array}$ & $\begin{array}{r}-0.008 \\
(0.04)\end{array}$ & $\begin{array}{l}0.029 \\
(0.05)\end{array}$ & $\begin{array}{r}-0.000 \\
(0.03)\end{array}$ & $\begin{array}{l}0.039 \\
(0.05)\end{array}$ & $\begin{array}{l}0.140 \text { ** } \\
(0.05)\end{array}$ & $\begin{array}{l}0.054 \\
(0.04)\end{array}$ & $\begin{array}{l}0.097 \text { ** } \\
(0.03)\end{array}$ & $\begin{array}{l}0.046 \\
(0.03)\end{array}$ & $\begin{array}{r}-0.012 \\
(0.03)\end{array}$ \\
\hline Leverage 4 / & $\begin{array}{l}0.009 \\
(0.01)\end{array}$ & $\begin{array}{r}-0.002 \\
(0.00)\end{array}$ & $\begin{array}{l}0.000 \\
(0.00)\end{array}$ & $\begin{array}{r}-0.000 \\
(0.00)\end{array}$ & $\begin{array}{l}-0.003^{* *} \\
(0.00)\end{array}$ & $\begin{array}{l}0.000 \\
(0.00)\end{array}$ & $\begin{array}{r}-0.001 \\
(0.00)\end{array}$ & $\begin{array}{l}0.002 \\
(0.00)\end{array}$ & $\begin{array}{r}-0.002 \\
(0.00)\end{array}$ & $\begin{array}{c}-0.002 \\
(0.00)\end{array}$ \\
\hline \multirow[t]{2}{*}{ Uncertainty $5 /$} & $\begin{array}{r}-0.049 \\
(0.11)\end{array}$ & $\begin{array}{c}-0.108 \text { * } \\
(0.06)\end{array}$ & $\begin{array}{c}-0.129 * \\
(0.07)\end{array}$ & $\begin{array}{r}-0.055 \\
(0.05)\end{array}$ & $\begin{array}{l}-0.1566^{* *} \\
(0.07)\end{array}$ & $\begin{array}{r}-0.013 \\
(0.04)\end{array}$ & $\begin{array}{r}-0.038 \\
(0.05)\end{array}$ & $\begin{array}{r}-0.072 \\
(0.08)\end{array}$ & $\begin{array}{c}-0.085 * \\
(0.05)\end{array}$ & $\begin{array}{c}-0.103 * \\
(0.05)\end{array}$ \\
\hline & \multicolumn{10}{|c|}{ p-value of specification tests } \\
\hline $\begin{array}{l}\mathrm{m} 1 \\
\text { m2 } \\
\text { Hansen-test }\end{array}$ & $\begin{array}{l}0.074 \\
0.526 \\
0.505\end{array}$ & $\begin{array}{l}0.000 \\
0.757 \\
0.512\end{array}$ & $\begin{array}{l}0.001 \\
0.376 \\
0.161\end{array}$ & $\begin{array}{l}0.000 \\
0.187 \\
0.259\end{array}$ & $\begin{array}{l}0.000 \\
0.083 \\
0.173\end{array}$ & $\begin{array}{l}0.000 \\
0.694 \\
0.550\end{array}$ & $\begin{array}{l}0.005 \\
0.087 \\
0.272\end{array}$ & $\begin{array}{l}0.015 \\
0.200 \\
0.396\end{array}$ & $\begin{array}{l}0.000 \\
0.088 \\
0.275\end{array}$ & $\begin{array}{l}0.001 \\
0.558 \\
0.873\end{array}$ \\
\hline $\begin{array}{l}\text { Number of firms } \\
\text { Number of observation }\end{array}$ & $\begin{array}{r}607 \\
1634\end{array}$ & $\begin{array}{r}3085 \\
13150\end{array}$ & $\begin{array}{l}1622 \\
7110\end{array}$ & $\begin{array}{l}1703 \\
6685\end{array}$ & $\begin{array}{l}1695 \\
9531\end{array}$ & $\begin{array}{l}1528 \\
5253\end{array}$ & $\begin{array}{l}2182 \\
7657\end{array}$ & $\begin{array}{l}1445 \\
4461\end{array}$ & $\begin{array}{l}2137 \\
9966\end{array}$ & $\begin{array}{l}1086 \\
4818\end{array}$ \\
\hline \multirow{2}{*}{ Japan } & \multicolumn{2}{|c|}{ Time period } & \multicolumn{2}{|c|}{ Size } & \multicolumn{2}{|c|}{ Market exposure } & \multicolumn{2}{|c|}{ Capital intensity } & \multicolumn{2}{|c|}{ Sector } \\
\hline & Precrisis & Postcrisis & Big & Small & Foreign & Domestic & High & Low 1 & Manufacturing & Services \\
\hline Tobin's $Q$ & $\begin{array}{l}0.017^{* *} \\
(0.01)\end{array}$ & $\begin{array}{l}0.005^{*} \\
(0.00)\end{array}$ & $\begin{array}{l}0.005^{*} \\
(0.00)\end{array}$ & $\begin{array}{l}0.004 \\
(0.00)\end{array}$ & $\begin{array}{l}0.008^{* *} \\
(0.00)\end{array}$ & $\begin{array}{l}0.005 \\
(0.00)\end{array}$ & $\begin{array}{l}0.010^{* *} \\
(0.00)\end{array}$ & $\begin{array}{l}0.004 \\
(0.00)\end{array}$ & $\begin{array}{l}0.012^{* *} \\
(0.00)\end{array}$ & $\begin{array}{l}0.002 \\
(0.00)\end{array}$ \\
\hline Liquidity $3 /$ & $\begin{array}{r}-0.179 \\
(0.13)\end{array}$ & $\begin{array}{l}0.045 \\
(0.04)\end{array}$ & $\begin{array}{l}0.012 \\
(0.05)\end{array}$ & $\begin{array}{l}0.089 * \\
(0.06)\end{array}$ & $\begin{array}{r}-0.012 \\
(0.04)\end{array}$ & $\begin{array}{l}0.103 * \\
(0.06)\end{array}$ & $\begin{array}{r}-0.019 \\
(0.06)\end{array}$ & $\begin{array}{l}0.103 \text { ** } \\
(0.05)\end{array}$ & $\begin{array}{l}0.038 \\
(0.05)\end{array}$ & $\begin{array}{l}0.092 * \\
(0.06)\end{array}$ \\
\hline Leverage 4 / & $\begin{array}{l}0.000 \\
(0.00)\end{array}$ & $\begin{array}{l}-0.002^{* *} \\
(0.00)\end{array}$ & $\begin{array}{l}-0.002 \text { ** } \\
(0.00)\end{array}$ & $\begin{array}{l}-0.002 \text { ** } \\
(0.00)\end{array}$ & $\begin{array}{l}-0.0022^{* *} \\
(0.00)\end{array}$ & $\begin{array}{c}-0.001 * \\
(0.00)\end{array}$ & $\begin{array}{l}-0.002 \text { ** } \\
(0.00)\end{array}$ & $\begin{array}{l}-0.002 \text { ** } \\
(0.00)\end{array}$ & $\begin{array}{l}-0.0022^{* *} \\
(0.00)\end{array}$ & $\begin{array}{l}-0.0022^{* *} \\
(0.00)\end{array}$ \\
\hline \multirow[t]{2}{*}{ Uncertainty $5 /$} & $\begin{array}{r}-0.033 \\
(0.09)\end{array}$ & $\begin{array}{l}-0.063^{* *} \\
(0.03)\end{array}$ & $\begin{array}{l}-0.072^{* *} \\
(0.03)\end{array}$ & $\begin{array}{r}-0.057 \\
(0.04)\end{array}$ & $\begin{array}{c}-0.0544^{*} \\
(0.03)\end{array}$ & $\begin{array}{r}-0.011 \\
(0.03)\end{array}$ & $\begin{array}{c}-0.088 \text { ** } \\
(0.03)\end{array}$ & $\begin{array}{c}-0.064 \text { ** } \\
(0.03)\end{array}$ & $\begin{array}{r}-0.042 \\
(0.03)\end{array}$ & $\begin{array}{r}-0.024 \\
(0.04)\end{array}$ \\
\hline & \multicolumn{10}{|c|}{ p-value of specification tests } \\
\hline $\begin{array}{l}\mathrm{m} 1 \\
\mathrm{~m} 2 \\
\text { Hansen-test }\end{array}$ & $\begin{array}{r}0.000 \\
0.52 \\
0.344\end{array}$ & $\begin{array}{l}0.000 \\
0.150 \\
0.267\end{array}$ & $\begin{array}{l}0.000 \\
0.211 \\
0.185\end{array}$ & $\begin{array}{l}0.000 \\
0.220 \\
0.625\end{array}$ & $\begin{array}{l}0.000 \\
0.120 \\
0.131\end{array}$ & $\begin{array}{l}0.000 \\
0.165 \\
0.852\end{array}$ & $\begin{array}{l}0.000 \\
0.734 \\
0.322\end{array}$ & $\begin{array}{l}0.000 \\
0.207 \\
0.271\end{array}$ & $\begin{array}{l}0.000 \\
0.856 \\
0.253\end{array}$ & $\begin{array}{l}0.000 \\
0.201 \\
0.916\end{array}$ \\
\hline $\begin{array}{l}\text { Number of firms } \\
\text { Number of observation }\end{array}$ & $\begin{array}{r}356 \\
1256\end{array}$ & $\begin{array}{l}2529 \\
9393\end{array}$ & $\begin{array}{l}1244 \\
5298\end{array}$ & $\begin{array}{l}1553 \\
4590\end{array}$ & $\begin{array}{l}1014 \\
5102\end{array}$ & $\begin{array}{l}1681 \\
5547\end{array}$ & $\begin{array}{l}1371 \\
4869\end{array}$ & $\begin{array}{l}1395 \\
4465\end{array}$ & $\begin{array}{l}1635 \\
7029\end{array}$ & $\begin{array}{l}1060 \\
3620\end{array}$ \\
\hline
\end{tabular}


In the NIEs, such effects seem to be evident in the services sector. In Japan, they inhibit investment by smaller firms, nonexporters, and those using labor-intensive technology. The results suggest that greater reliance on equity could promote investment by such firms.

- Uncertainty also has powerful dampening effects on investment in the services sector in the NIEs and labor-intensive firms in Japan. In part, the effect of uncertainty may reflect the close integration of these economies with global markets and their associated susceptibility to global shocks (Figure 11). In addition, with greater competition at each step of the supply chain, firms might be less able to adjust markups procyclically and

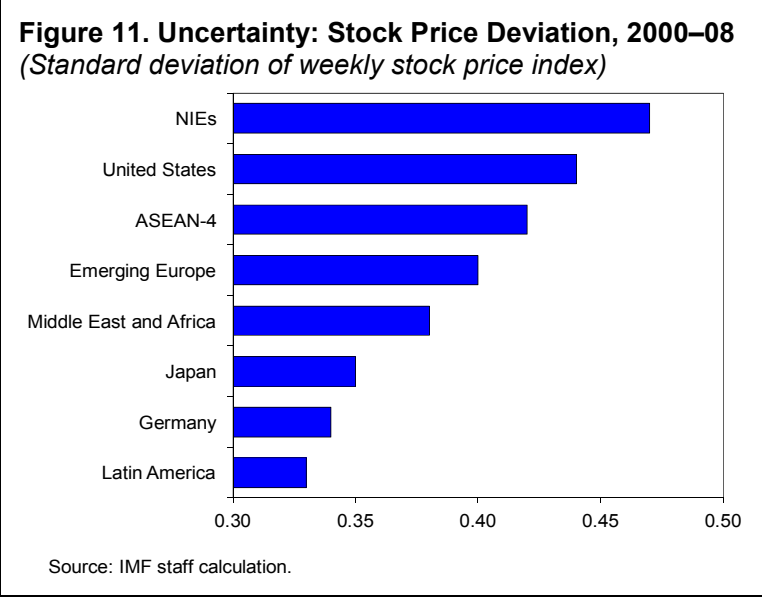
use them as buffers against external shocks. This may have made them more cautious in their investment decisions than they would have been previously. ${ }^{17}$

Overall, smaller, more domestically oriented, labor-intensive and service sector firms in the NIEs and in Japan have faced stronger headwinds to their investment compared with larger, exporting, capital-intensive, and manufacturing firms (Figure 12). These headwinds are reflected in the greater sensitivity of their investment to profitability, internal funding, leverage and risk, as well as the generally lower improvement in these indicators since the Asian crisis relative to the latter group of firms (Table 6). ${ }^{18}$

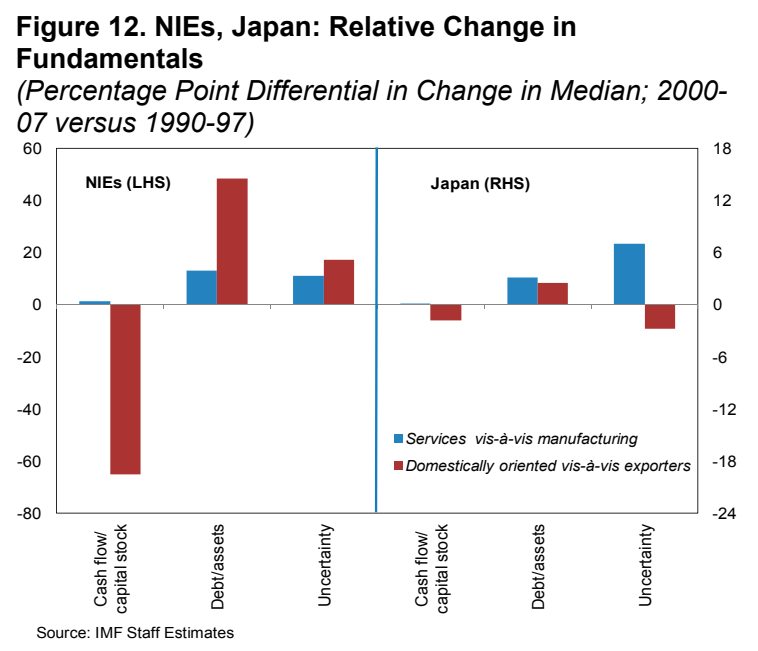

\footnotetext{
${ }^{17}$ Linden, Kraemer, and Dedrick (2009) illustrate the supply chain of the iPod and demonstrate how Asian firms capture very little of the value added at each stage compared with the share garnered by the U.S.-based providers of the intellectual capital behind the product, suggesting limited profit margins in the Asian segments of the chain.

${ }^{18}$ In the case of the ASEAN-4, financing constraints are found to be even more binding and to apply across a broader range of firms, while the detrimental effects of leverage and risk were mostly concentrated in larger firms and the export sector.
} 
Table 6. NIEs and Japan: Changes in Fundamentals, 1990-97 versus 2000-07 by Firm and Type

(Median)

\begin{tabular}{|c|c|c|c|c|c|c|}
\hline & \multicolumn{3}{|c|}{ NIEs } & \multicolumn{3}{|c|}{ Japan } \\
\hline & $1990-7$ & $2000-7$ & $\begin{array}{l}\text { Percent } \\
\text { change }\end{array}$ & 1990-7 & $2000-7$ & $\begin{array}{l}\text { Percent } \\
\text { change }\end{array}$ \\
\hline \multicolumn{7}{|l|}{ Small } \\
\hline Tobin's $Q$ & 2.9 & 2.1 & -28.0 & 3.2 & 1.5 & -52.7 \\
\hline $\mathrm{CF} / \mathrm{K}$ & 0.2 & 0.2 & 11.9 & 0.1 & 0.1 & 2.9 \\
\hline Debt/assets & 18.4 & 18.8 & 2.2 & 28.6 & 19.9 & -30.1 \\
\hline Uncertainty & 0.3 & 0.5 & 42.1 & 0.3 & 0.4 & 8.3 \\
\hline \multicolumn{7}{|l|}{ Large } \\
\hline Tobin's $Q$ & 2.5 & 1.9 & -24.6 & 2.5 & 1.7 & -30.7 \\
\hline $\mathrm{CF} / \mathrm{K}$ & 0.1 & 0.2 & 94.0 & 0.1 & 0.1 & 4.1 \\
\hline Debt/assets & 41.8 & 26.4 & -36.9 & 36.1 & 22.4 & -37.8 \\
\hline Uncertainty & 0.4 & 0.4 & 22.5 & 0.3 & 0.3 & 13.3 \\
\hline \multicolumn{7}{|l|}{ Services } \\
\hline Tobin's $Q$ & 2.8 & 1.9 & -30.1 & 4.5 & 1.7 & -62.7 \\
\hline $\mathrm{CF} / \mathrm{K}$ & 0.1 & 0.2 & 36.0 & 0.1 & 0.1 & 4.3 \\
\hline Debt/assets & 24.8 & 21.4 & -13.8 & 30.8 & 20.3 & -34.0 \\
\hline Uncertainty & 0.3 & 0.5 & 36.7 & 0.3 & 0.3 & 10.7 \\
\hline \multicolumn{7}{|l|}{ Manufacturing } \\
\hline Tobin's $Q$ & 2.6 & 1.9 & -27.9 & 2.6 & 1.6 & -39.4 \\
\hline $\mathrm{CF} / \mathrm{K}$ & 0.1 & 0.2 & 34.7 & 0.1 & 0.1 & 4.2 \\
\hline Debt/assets & 32.7 & 23.9 & -26.9 & 35.0 & 22.0 & -37.1 \\
\hline Uncertainty & 0.4 & 0.4 & 25.6 & 0.3 & 0.3 & 3.7 \\
\hline \multicolumn{7}{|l|}{ Domestic } \\
\hline Tobin's $Q$ & 3.1 & 1.9 & -39.2 & 3.4 & 1.5 & -56.0 \\
\hline $\mathrm{CF} / \mathrm{K}$ & 0.2 & 0.2 & -18.4 & 0.1 & 0.1 & 2.1 \\
\hline Debt/assets & 19.8 & 23.6 & 19.4 & 30.2 & 20.4 & -32.4 \\
\hline Uncertainty & 0.3 & 0.5 & 48.0 & 0.3 & 0.3 & 7.8 \\
\hline \multicolumn{7}{|l|}{ Exporters } \\
\hline Tobin's $Q$ & 2.6 & 2.1 & -19.5 & 2.7 & 1.8 & -36.1 \\
\hline $\mathrm{CF} / \mathrm{K}$ & 0.1 & 0.2 & 46.6 & 0.1 & 0.2 & 3.9 \\
\hline Debt/assets & 31.3 & 22.2 & -29.0 & 34.4 & 22.4 & -34.9 \\
\hline Uncertainty & 0.4 & 0.5 & 30.7 & 0.3 & 0.3 & 10.6 \\
\hline \multicolumn{7}{|l|}{ Labor-intensive } \\
\hline Tobin's $Q$ & 3.4 & 2.5 & -27.2 & 3.5 & 1.8 & -48.6 \\
\hline $\mathrm{CF} / \mathrm{K}$ & 0.2 & 0.2 & 9.2 & 0.2 & 0.2 & 10.4 \\
\hline Debt/assets & 22.2 & 18.5 & -16.9 & 27.9 & 19.3 & -30.9 \\
\hline Uncertainty & 0.3 & 0.5 & 39.3 & 0.3 & 0.3 & 15.2 \\
\hline \multicolumn{7}{|c|}{ Capital-intensive } \\
\hline Tobin's $Q$ & 2.4 & 1.7 & -27.1 & 2.5 & 1.5 & -40.9 \\
\hline $\mathrm{CF} / \mathrm{K}$ & 0.1 & 0.2 & 51.0 & 0.1 & 0.1 & 3.3 \\
\hline Debt/assets & 32.5 & 26.5 & -18.6 & 38.6 & 24.1 & -37.7 \\
\hline Uncertainty & 0.4 & 0.5 & 30.8 & 0.3 & 0.3 & 2.3 \\
\hline
\end{tabular}

Source: IMF staff estimates. 
Finally, many of the constraints on investment identified in Asia appear to be specific to the region and do not affect firms in other emerging and advanced economies to the same extent (Table 7):

\begin{tabular}{|c|c|c|c|c|c|c|}
\hline & $\begin{array}{l}\text { Emerging } \\
\text { Europe }\end{array}$ & $\begin{array}{l}\text { Middle East } \\
\text { and Africa }\end{array}$ & $\begin{array}{l}\text { Latin } \\
\text { America }\end{array}$ & $\begin{array}{l}\text { United } \\
\text { States }\end{array}$ & $\begin{array}{l}\text { United } \\
\text { Kingdom }\end{array}$ & Germany \\
\hline Tobin's $Q$ & $\begin{array}{l}0.010 \\
(0.01)\end{array}$ & $\begin{array}{c}0.015^{\star *} \\
(0.01)\end{array}$ & $\begin{array}{l}0.004 \\
(0.01)\end{array}$ & $\begin{array}{c}0.010^{* *} \\
(0.00)\end{array}$ & $\begin{array}{c}0.010^{* *} \\
(0.00)\end{array}$ & $\begin{array}{c}0.014^{\star *} \\
(0.00)\end{array}$ \\
\hline Liquidity & $\begin{array}{c}0.119^{\star *} \\
(0.05)\end{array}$ & $\begin{array}{l}0.051^{*} \\
(0.03)\end{array}$ & $\begin{array}{c}0.247^{* *} \\
(0.06)\end{array}$ & $\begin{array}{l}0.016 \\
(0.01)\end{array}$ & $\begin{array}{l}-0.010 \\
(0.02)\end{array}$ & $\begin{array}{l}0.029^{*} \\
(0.02)\end{array}$ \\
\hline Leverage & $\begin{array}{l}-0.000 \\
(0.00)\end{array}$ & $\begin{array}{l}0.000 \\
(0.00)\end{array}$ & $\begin{array}{l}-0.001 \\
(0.00)\end{array}$ & $\begin{array}{l}0.002 \\
(0.01)\end{array}$ & $\begin{array}{l}0.001 \\
(0.00)\end{array}$ & $\begin{array}{l}-0.001 \\
(0.00)\end{array}$ \\
\hline Uncertainty & $\begin{array}{l}0.111 \\
(0.11)\end{array}$ & $\begin{array}{l}-0.048 \\
(0.07)\end{array}$ & $\begin{array}{l}-0.050 \\
(0.06)\end{array}$ & $\begin{array}{c}-0.032^{*} \\
(0.02)\end{array}$ & $\begin{array}{c}-0.129^{* *} \\
(0.06)\end{array}$ & $\begin{array}{l}0.033 \\
(0.07)\end{array}$ \\
\hline \multicolumn{7}{|c|}{$p$-value of specification tests } \\
\hline $\mathrm{m} 1$ & 0.001 & 0.000 & 0.000 & 0.000 & 0.000 & 0.001 \\
\hline $\mathrm{m} 2$ & 0.488 & 0.186 & 0.156 & 0.128 & 0.546 & 0.150 \\
\hline Hansen-test & 0.814 & 0.278 & 0.196 & 0.335 & 0.858 & 0.677 \\
\hline Number of firms & 410 & 451 & 566 & 4295 & 1197 & 634 \\
\hline Number of observations & 1610 & 2404 & 3528 & 19669 & 5901 & 3095 \\
\hline
\end{tabular}

- In other emerging economies, investment is less affected by risk or capital structure. The detrimental effects of uncertainty and the overhang of debt were less pronounced than in Asia reflecting, respectively, the relatively more open nature of Asian economies, and the relatively heavier reliance of Asian firms on short-term funding.

- $\quad$ Outside the region, financing constraints and leverage do not have as dominant a role in advanced economies with well-developed capital markets. German firms, which operate in a similar bank-oriented financing environment as firms in the NIEs and Japan, display the same cross-sectional pattern in financing constraints. However, there is less evidence in recent years of financing constraints or detrimental effects of debt financing in the case of firms in the United States and United Kingdom, partly reflecting more diverse sources of funding for small companies, including bond markets, equity funding, and venture capital. 


\section{Policy Implications: How Can Asia Facilitate Rebalancing Through INVESTMENT?}

To help rebalance Asia's economies, private investment needs to be raised in some cases, such as the ASEAN-4, while in other economies, such as Japan and the NIEs, it needs to be reconfigured toward domestically oriented sectors. At the same time, the region's pressing infrastructure needs are a constraint on private investment and growth and will have to be addressed urgently. This section discusses potential policy responses to meet these challenges suggested by the econometric results and best practices for funding infrastructure investments based on cross-country evidence.

\section{A. Policies Suggested by Empirical Results}

The empirical results presented in this chapter suggest that policies to boost private investment could focus on four broad areas (Table 8): (1) increasing the returns on investment; (2) improving access to external financing to reduce the cost of capital, especially for smaller and domestically oriented firms; (3) reducing excess leverage and promoting SME restructuring to create space for new investment; and (4) strengthening risk management and bolstering the business climate to reduce uncertainty.

First, raising the rate of return on investment will be important, suggesting these strategies:

- In some parts of the region, the tax code is an obvious candidate, since taxes raise the bar for investment to be profitable and fall especially hard on capital-intensive industries. Japan, for instance, has among the

\begin{tabular}{|c|c|c|c|}
\hline Drivers & Region & Type of firm & $\begin{array}{l}\text { Effect on } \\
\text { investment }\end{array}$ \\
\hline $\begin{array}{l}10 \text { percent } \\
\text { increase in } \\
\text { profitability }\end{array}$ & $\begin{array}{l}\text { NIEs } \\
\text { ASEAN-4 }\end{array}$ & $\begin{array}{l}\text { Small firms } \\
\text { Large firms }\end{array}$ & $\begin{array}{l}3 \text { percent } \\
2 \text { percent }\end{array}$ \\
\hline \multirow[t]{2}{*}{$\begin{array}{l}10 \text { percent } \\
\text { increase in } \\
\text { external finance }\end{array}$} & NIEs & $\begin{array}{l}\text { Domestically } \\
\text { oriented; labor- } \\
\text { intensive }\end{array}$ & 2 percent \\
\hline & $\begin{array}{l}\text { Japan, } \\
\text { ASEAN-4 }\end{array}$ & $\begin{array}{l}\text { Small firms; } \\
\text { domestically } \\
\text { oriented; service } \\
\text { sector }\end{array}$ & 2 percent \\
\hline \multirow{3}{*}{$\begin{array}{l}10 \text { percent } \\
\text { decrease in } \\
\text { leverage }\end{array}$} & NIEs & Service sector & 3 percent \\
\hline & Japan & $\begin{array}{l}\text { Small firms; } \\
\text { domestically } \\
\text { oriented; labor- } \\
\text { intensive; service } \\
\text { sector }\end{array}$ & $\begin{array}{c}2-5 \\
\text { percent }\end{array}$ \\
\hline & ASEAN-4 & $\begin{array}{l}\text { Large firms; } \\
\text { export oriented; } \\
\text { manufacturing } \\
\text { sector }\end{array}$ & $\begin{array}{c}4-6 \\
\text { percent }\end{array}$ \\
\hline \multirow{3}{*}{$\begin{array}{l}10 \text { percent } \\
\text { decrease in risk }\end{array}$} & NIEs & Service sector & 4 percent \\
\hline & Japan & $\begin{array}{l}\text { Labor-intensive } \\
\text { firms }\end{array}$ & 3 percent \\
\hline & ASEAN-4 & $\begin{array}{l}\text { Export oriented; } \\
\text { manufacturing } \\
\text { sector; capital- } \\
\text { intensive firms }\end{array}$ & $\begin{array}{l}3-5 \\
\text { percent }\end{array}$ \\
\hline
\end{tabular}
highest average and marginal effective corporate tax rates (AER and MER) in the OECD (Figure 13). ${ }^{19}$ Lowering the corporate tax rate may be an effective strategy for

\footnotetext{
${ }^{19}$ The average effective rate (AER) is the proportion of lifetime pretax profit that is taken in tax and is an important determinant of the location of investment. The marginal effective tax rate (MER) is the difference
}

(continued...) 
reducing distortions and boosting domestic and foreign investment. Extending corporate tax-loss carryforwards to allow firms to recoup some of the losses incurred in the early years of large investments may also help, although the impact on corporate tax revenue would also need to be carefully considered. (Syed and Lee, 2010). ${ }^{20}$ Elsewhere, such as in Korea where effective tax rates are already low by OECD standards due to

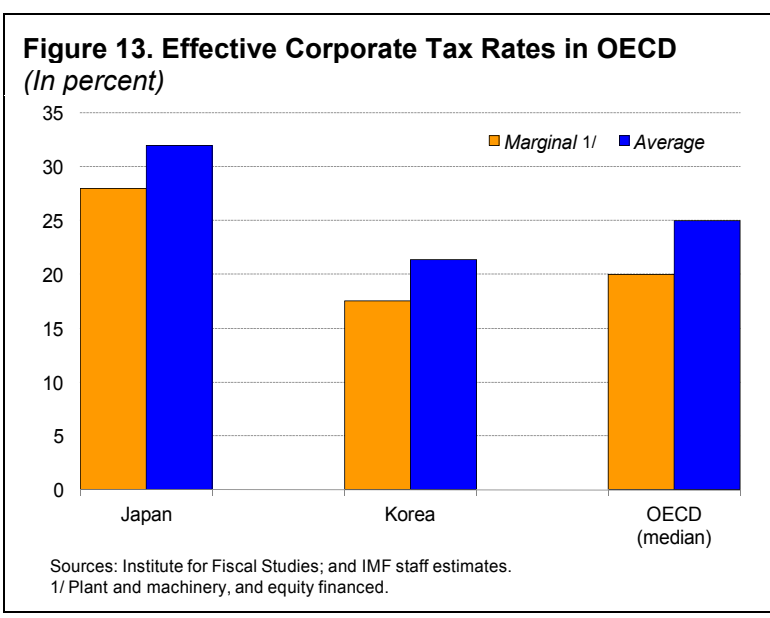
generous tax exemptions, changes in taxation are likely to have a more modest impact. $^{21}$

- $\quad$ On the other hand, tax incentives are unlikely to be cost-effective. ${ }^{22}$ Their key weaknesses include costliness, scope for abuse by taxpayers, lack of transparency, introducing distortions into business decisions, and ineffectiveness, relative to other measures, in reaching intended goals. Instead, international evidence suggests that establishing a simple, credible, broad-based and transparent corporate tax regime may be a better strategy for creating an environment conducive to investment (Botman, Klemm, and Baqir, 2008).

Second, improving access to external financing would lower the cost of capital for smaller businesses and firms in the nontradable sectors. Problems faced by SMEs in accessing financing typically reflect an incomplete range of financial products, regulatory rigidities, gaps in the legal framework, and information asymmetries between financiers and firms. Possible strategies to mitigate these effects include:

- Deepening and broadening financial systems. Only Korea and Malaysia have sizable corporate bond markets among emerging economies in the region, while the rest rely on relationship-based financing through banks (Figure 14). Encouraging corporate

between the before- and after-tax returns on a project that an investor finds just worthwhile; it affects the desired level of investment.

${ }^{20}$ Japan currently allows for a seven-year carry- forward period, compared with 20 years in the United States.

${ }^{21}$ A wide range of incentives are currently provided under the special tax treatment and control law of 1999. Moreover, the literature suggests that tax effects on investment may be secondary if other factors, such as the quality of governance, regulatory framework, infrastructure, macropolitical stability, and labor market conditions, are problematic. See Norregaard and Khan (2007) for a review.

${ }^{22}$ Among others, see Zee, Stotsky, and Ley (2002) for a survey of the evidence. 
bond market development would help open up additional channels for funding (IMF, 2007).

- Improving the financial infrastructure for smaller and more service-oriented firms by encouraging more lending on risk-based terms; reforming collateral laws to allow a wider range of securitization (beyond real estate and other fixed assets), as is being done in Japan through a program accepting inventories and accounts receivables as

Figure 14. Size of the Corporate Bond Market, Selected Asian Economies, 2009 (In percent of GDP)

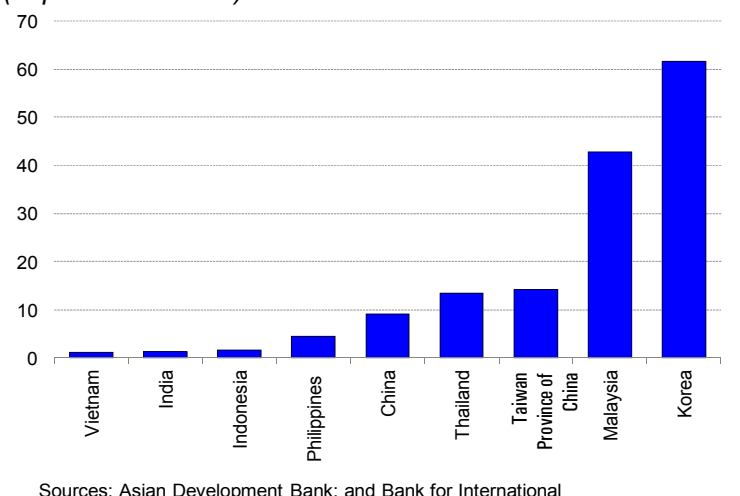

Sources: Asian Development Bank; and Bank for International

collateral; and deepening credit information and extending the coverage of credit registries. The latter was initiated in the Philippines through the establishment of the Credit Information Corporation in 2008.

- Widening the pool of venture capital funding available for start-ups in new emerging sectors. Targeted tax breaks or allocations of a larger share of public pension funds to venture capital investments could support the industry, which is relatively underdeveloped, even in advanced parts of Asia (Figure 15). ${ }^{23}$ More funding could also be drawn in by providing information on venture capital investment performance and developing performance benchmarks on emerging

Figure 15. Venture Capital Investment: Selected Advanced Economies, 2006 (In percent of GDP)

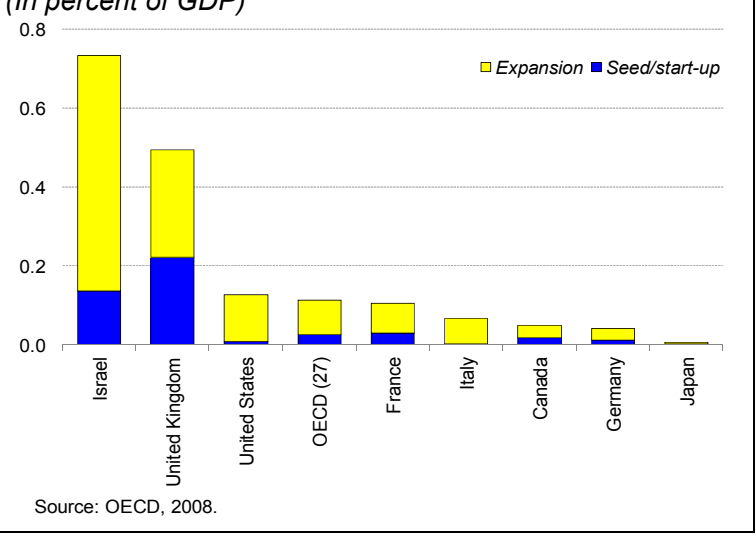
equity exchanges (such as JASDAQ in Japan). ${ }^{24}$

Third, reducing leverage and improving incentives for corporate restructuring will help create space for new investment:

\footnotetext{
${ }^{23}$ In Japan, for instance, the Government Pension Investment Fund does not undertake any alternative investments such as venture capital, real estate, and private equity. By contrast, a number of OECD countries allocate some share of their assets to such investments, including California Public Employees' Retirement System (14 percent) and New Zealand Superannuation Fund (11 percent). See also IMF (2010b).

${ }^{24}$ In the United States and Europe, VentureOne and Thomson Financial store information on startups-including profitability and investment flows-regularly used by venture capitalists and institutional investors.
} 
- $\quad$ As the global recovery firms up, restructuring could be promoted by phasing out credit guarantees. Significant progress has been made on corporate and financial restructuring over the last decade, but smaller companies have tended to fall behind (IMF, 2006a, 2006b). This partly reflects the still-sizable credit guarantees for SMEs, which can limit their incentives for restructuring and create an entry barrier by making it difficult for many newer firms to access bank credit (McKinsey, 2000). ${ }^{25}$ In Korea, for instance, banks tend to direct loans to existing and well-established SMEs that have secured credit guarantees, since most of the associated default risk is borne by the government. While these guarantees declined from 8 percent of GDP in 2001 to about 6 percent in 2005, they remained almost 30 times larger than in the United States. ${ }^{26}$ Over the longer term, attention should shift away from relying on guarantees to addressing the root cause of SMEs' limited access to credit.

Improvements in the financial infrastructure can improve credit availability, including by expanding credit information sharing, allowing the securitization of movable assets, and developing venture capital markets for SMEs (Beck and Demirgüç-Kunt, 2006).

- $\quad$ Assisting the exit of nonviable companies would also help, including through out-ofcourt workouts and further reforms to streamline bankruptcy procedures. Combined with reforms to the public support system, these measures could jumpstart a market for private-led restructuring of distressed SMEs, similar to what took place for large enterprises after the Japanese banking crisis in the 1990s. In the same vein, after the Asian crisis, the Korea Asset Management Corporation successfully created a market for distressed Korean corporate debt by purchasing nonperforming loans (NPLs) from banks and repackaging them for eventual sale to investors. ${ }^{27}$ A similar restructuring and consolidation of the SME sector might be accomplished by promoting asset management companies that specialize in repackaging distressed debt of small firms.

Fourth, reducing uncertainty would help lower the risks associated with long-term investment decisions. The empirical results suggest that investment decisions can be affected by uncertainty about many aspects of the operating environment, such as demand, prices, costs, and exchange rates. In addition, risk related to policies, notably the tax code and other business regulations, could deter private investment. Options to address this include:

- $\quad$ Promoting the use of financial instruments to manage risks. Even in relatively advanced parts of the region, international comparisons suggest that large exporters

\footnotetext{
${ }^{25}$ Uesugi, Sakai, and Yamashiro, 2006, suggest that credit guarantees can lead to a significant increase in leverage and do not translate into efficiency gains in the case of high-risk firms.

${ }^{26}$ More recently, credit guarantees have increased significantly across the region as part of the policy response to the crisis (see Box 1.7 in IMF, 2009a).

${ }^{27}$ See Kang and Kim (2006).
} 
tend to underinsure against credit, commodity, and marketable security price risk. SMEs undertake much less hedging in general (Heaney and others, 1999).

- $\quad$ Further improvements to the perceptions of the ease of doing business. While the structural reforms implemented since the Asian crisis have potentially made a substantive difference in the region's investment climate, it appears that perceptions have not yet caught up with the new reality. Surveys suggest that a streamlined process for business creation, greater labor market flexibility, an improved legal and regulatory framework for entrepreneurs and bankruptcy, and a more transparent tax system could help reduce investor perceptions of risk in many parts of the region (Guimaraes and Unteroberdoerster, 2006; and IMF, 2008b). Ongoing efforts in these areas - the adoption of a competition law in Hong Kong SAR, the lowering of restrictions on foreign investment in the services sector in Malaysia, the establishment of one-stop shops to reduce administrative delays in Indonesia and Malaysia - could make it more attractive for companies to expand operations domestically rather than overseas.

\section{B. Meeting Infrastructure Needs}

Government financing and provision of infrastructure may not be sufficient to meet the growing needs of the region. Over the next decade, emerging Asia's total infrastructure needs are estimated to be in the vicinity of US\$7.5 trillion (AsDB, 2009). While several governments across the region have stepped up their allocation to infrastructure as part of crisis-induced stimulus packages, their ability to sustain elevated levels of investment in roads, telecommunications, and electricity in the years ahead may be limited by other demands on their budgets, shrinkages in fiscal space, and diminishing tolerance of bond investors for rising sovereign expenditure. ${ }^{28}$

Public-private partnerships offer an alternative provision mechanism, but effective design of these vehicles calls for coordinated action on many fronts. Historically, the provision of infrastructure has been almost entirely in the public domain in Asia and elsewhere, including in advanced economies. As pressures on government budgets have intensified worldwide, more attention has been paid to hybrid public-private forms of provision. The projects initiated under this organizational form offer some important lessons for the design of future public-private partnerships:

- $\quad$ The Theun Hinboun hydropower project, implemented jointly by Thailand and Lao PDR between 1994 and 1998, has turned out to be highly profitable (AsDB,

\footnotetext{
${ }^{28}$ The disconnect between infrastructure finance needs and government ability to raise funding through general tax revenue is already acute in developing and emerging market contexts. Because the tax base tends to be narrower than in advanced economies, the marginal cost of generating additional revenue is likely to be relatively high (Swaroop, 1994).
} 
2009). Potential time inconsistency and hold-up problems (which may arise in instances where firms are asked to sink capital into a multiyear project but then are subsequently exposed to midcourse changes in tariff or tax policies) were solved by the Lao PDR government committing to meet its obligations under a 30-year license, backed up by the establishment of an offshore escrow account pledged to the investors in the project.

- $\quad$ The new international airport terminals at Delhi and Mumbai have been financed through a joint venture with 74 percent private consortium equity. Construction began in 2006 and is nearing completion in both cities. Regulatory uncertainty has been mitigated by having a dedicated regulator with sole legal jurisdiction over the projects. The new Airports Economic Regulatory Authority is focused entirely on monitoring services at the airports and has laid out clear ex ante guidelines on pricing and cost pass-through and the quality of services.

A general principle in public-private partnerships is that optimal risk sharing involves allocating the burden of a particular risk to the entity best placed to bear it. Construction and operating risks are best borne by the private concessionary while the government entity bears the political and regulatory risks (Akitoby, Hemming, and Schwartz, 2007). A transparent sharing of risks along these lines can minimize delays, cost overruns, and funding disruptions. At the same time, the delineation of risks may be blurred if, for example, the government guarantees the debt raised by the private entity. In such instances, a clear accounting of the contingent fiscal risk will help anchor expectations and align sovereign borrowing costs more closely with fundamentals.

Measures to unlock saving and channel it into targeted infrastructure investment funds may help meet some of the funding shortfall. An innovation under consideration in India is the establishment of dedicated funding intermediaries with well-defined capital adequacy norms that can issue tax-free infrastructure bonds and tap into pension and insurance fund holdings. This will help overcome the problems of a bank-heavy funding structure where banks typically encounter an asset-liability mismatch when they lend long-term to infrastructure projects but rely largely on short-term wholesale funding and retail deposits.

\section{Summary}

Looking ahead, a strategy for rebalancing growth in Asia will have many dimensions. One such dimension is the level and composition of investment. In some economies, such as the ASEAN-4, investment appears to be low relative to the level of development. In other parts of the region, such as Japan and the NIEs, the composition of investment is skewed toward export-oriented, capital-intensive firms in the manufacturing sector to the detriment of domestically oriented, labor-intensive firms in the services sector. 
The pattern of investment could be influenced by financial reforms and improvements in infrastructure. In Japan and the NIEs, increasing investment by smaller, domestically oriented firms would help rotate the composition of investment toward nontradable sectors and promote rebalancing. Policies likely to advance this objective include promoting riskbased financing, SME restructuring through the reform of bankruptcy laws, and streamlining tax codes and regulations. In the ASEAN-4 economies, where the main concern is the overall level of investment, improvements in infrastructure could also help crowd in private investment and lift potential growth. How Asia adjusts to the postcrisis world of reduced external demand depends crucially on whether the region's economies create conditions conducive to investment-led rebalancing. 


\section{REFERENCES}

Abiad, A., E. Detragiache, and T. Tresse, 2008, "A New Database of Financial Reforms," IMF Working Paper No. 08/266 (Washington: International Monetary Fund).

Abiad, A., D. Leigh, and M. Terrones, 2010, "Getting the Balance Right: Transitioning Out of Sustained Current Account Surpluses," World Economic Outlook (Washington: International Monetary Fund), April.

Akitoby, B., R. Hemming, and G. Schwartz, 2007, "Public Investment and Public-Private Partnerships," Economic Issues, Vol. 40 (Washington: International Monetary Fund).

Asian Development Bank, 2009, "Infrastructure for a Seamless Asia" (Manila).

Barclays Capital, 2009, "Correcting Global Imbalances: A Policy Prescription for Emerging Asia” (unpublished; London: Barclays Emerging Markets Research).

Beck, T., A. Demirgüc-Kunt, 20036, "Small and Medium Enterprises: Access to Finance as a Growth Contraint," Journal of Banking and Finance, Vo. 30, pp. 2931-2943.

Blanchard, O., and G. M. Milesi-Ferretti, 2009, "Global Imbalances: In Midstream,” IMF Staff Position Note No. 09/29 (Washington: International Monetary Fund).

Botman, D., A. Klemm, and R. Baqir, 2008, "Investment Incentives and Effective Tax Rates in the Philippines: A Comparison with Neighboring Countries," IMF Working Paper No. 08/207 (Washington: International Monetary Fund).

Calderon, C., and L. Serven, 2004a, "The Effects of Infrastructure Development on Growth and Income Distribution," Policy Research Working Paper No. 3400 (Washington: World Bank).

_ 2004b, "Trends in Infrastructure in Latin America, 1980-2001," Policy Research Working Paper No. 3401 (Washington: World Bank).

Cardarelli, R., and A. Rebucci, 2007, "Exchange Rates and the Adjustment of External Imbalances," World Economic Outlook (Washington: International Monetary Fund), April.

and M. Terrones, 2005, "Global Imbalances: A Saving and Investment Perspective," World Economic Outlook (Washington: International Monetary Fund), September.

DeLong, J. B., 2002, "Productivity Growth in the 2000s," in NBER Macroeconomics Annual, Vol. 17, ed. by M. Gertler and K. Rogoff (Cambridge, Massachusetts: National Bureau of Economic Research). 
Devarajan, S., V. Swaroop, and H. Zhou, 1996, "The Composition of Public Expenditure and Economic Growth,” Journal of Monetary Economics, Vol. 37, pp. 313-44.

Guimaraes, R., and O. Unteroberdoerster, 2006, "What's Driving Private Investment in Malaysia? Aggregate Trends and Firm-Level Evidence," IMF Working Paper No. 06/190 (Washington: International Monetary Fund).

Heaney, R., C. Koga, B. Oliver, and A. Tran, 1999, "The Size Effect and Derivative Usage in Japan," Working Paper Series in Finance 99-02 (The Australian National University: Canbera).

Hori, M., 2008, "Investment Recovery from Financial Crises," in IMF Country Report No. 08/194 (Washington: International Monetary Fund, June).

Hsieh, C.T., and P. Klenow, 2007, "Relative Prices and Relative Prosperity," American Economic Review, Vol. 97, No. 3, pp. 562-85.

International Monetary Fund, 2006a, “Asia's Investment Slump," in Regional Economic Outlook: Asia and Pacific (Washington: International Monetary Fund, May).

_ 2006b. "Savings and Investment: An Emerging Asian and Singaporean Perspective," IMF Country Report No. 06/151 (Washington, May).

— 2007. "Investment Recovery from Financial Crises: A View from Cross-Country Experiences," IMF Country Report No. 07/231 (Washington, July).

— , 2008a, "What Determines Investment in Korea?" in Republic of Korea: Selected Issues, IMF Country Report No. 08/296 (Washington, September).

— 2008b, Regional Economic Outlook: Asia and Pacific (Washington: November).

— 2010. Japan: 2010 Article IV Consultation-Staff Report, IMF Country Report No. 10/211 (Washington).

Jensen, R., 2007, “The Digital Provide: Information (Technology), Market Performance, and Welfare in the South Indian Fisheries Sector," Quarterly Journal of Economics, Vol. 122, No. 3, pp. 879-924.

Kang, K., and S. Y. Kim, 2006, "A Strategy for Restructuring the SME Sector in Korea," IMF Country Report No. 06/381 (Washington: International Monetary Fund, October).

Krugman, P., 1991, "Increasing Returns and Economic Geography," The Journal of Political Economy, Vol. 99, No. 3, pp. 483-99. 
Linden, G., K. Kraemer, and J. Dedrick, 2009, "Who Captures Value in a Global Innovation Network? The Case of Apple's iPod," Communications of the Association for Computing Machinery, Vol. 52, No. 3, pp 140-44.

Lueth, E., C. Steinberg, and M. Syed, 2009, "Exit from SME Support Measures," in Regional Economic Outlook-Asia and Pacific (Washington: International Monetary Fund), October.

Mercereau, B., 2005, "FDI Flows to Asia: Did the Dragon Crowd-Out the Tigers?" IMF Working Paper No. 05/189 (Washington: International Monetary Fund).

McKinsey and Company, 2010, "Asian Financial Sector-The Changing Landscape," presented at Asia Banking and Finance Conference, Federal Reserve Bank of San Francisco (June).

Mohommad, A., P. N'Diaye, and O. Unteroberdoerster, 2010, "Does Asia Need Rebalancing?" in Regional Economic Outlook: Asia and Pacific (Washington: International Monetary Fund, April).

Norregaard, J. and T. Khan, 2007, “Tax Policy: Recent Trends,” IMF Working Paper No. 07/274 (Washington: International Monetary Fund).

Pritchett, L., 1996, "Mind Your Ps and Qs: The Cost of Public Investment is Not the Value of Public Capital," Policy Research Working Paper No. 1660 (Washington: World Bank).

Rangarajan, C., 2010, “Economic Outlook for 2010/11” (New Delhi: Prime Minister's Economic Advisory Council), available via the Internet at http://eac.gov.in/.

Straub, S., 2008, "Infrastructure and Growth in Developing Countries: Recent Advances and Research Challenges," Policy Research Working Paper No. 4460 (Washington: World Bank).

- C. Vellutini, and M. Walters, 2008, "Infrastructure and Economic Growth in East Asia,” Policy Research Working Paper 4589 (Washington: World Bank).

Swaroop, V., 1994, "The Public Financing of Infrastructure: Options and Issues," Policy Research Working Paper No. 1288 (Washington: World Bank).

Syed, M. and J. Lee, 2010, “Japan's Quest for Growth: Exploring the Role of Capital and Innovation,” IMF Working Paper No. 10/294 (Washington: International Monetary Fund).

Uesugi, I., K. Sakai, and G. Yamashiro, 2006, "Effectiveness of Credit Guarantees in the Japanese Loan Market," RIETI Discussion Paper No. 06-E-004 
Venables, A., 2006, "Shifts in Economic Geography and Their Causes," paper presented at the Federal Reserve Bank of Kansas City Symposium, The New Economic Geography: Effects and Policy Implications, August. Available via the Internet at http://KansasCityFed.org.

World Bank, 1994, "Infrastructure for Development," in World Development Report (Washington).

Young, A., 1995, "The Tyranny of Numbers: Confronting the Statistical Realities of the East Asian Growth Experience," Quarterly Journal of Economics, Vol. 110, No. 3, pp. 641-80.

Zee, H.H., J.G. Stotsky, and E. Ley, 2002, “Tax Incentives for Business Investment: A Primer for Policy Makers in Developing Countries," World Development, Vol. 3 , No. 9, pp. 1497-1516. 